\title{
The epidemiology of seasonal influenza after the 2009 influenza pandemic in Africa: a systematic review
}

\author{
Adamou Lagare ${ }^{1}$, Soatiana Rajatonirina ${ }^{2}$, Jean Testa ${ }^{1}$, Saidou Mamadou ${ }^{3}$
}

1. Centre de Recherche Médicale et Sanitaire (CERMES), Niamey, Niger.

2. World Health Organization, Regional Office for Africa, Brazzaville, Congo.

3. Université Abdou Moumouni, Niamey, Niger.

\begin{abstract}
Background: Influenza infection is a serious public health problem that causes an estimated 3 to 5 million cases and 250,000 deaths worldwide every year. The epidemiology of influenza is well-documented in high- and middle-income countries, however minimal effort had been made to understand the epidemiology, burden and seasonality of influenza in Africa. This study aims to assess the state of knowledge of seasonal influenza epidemiology in Africa and identify potential data gaps for policy formulation following the 2009 pandemic.

Method: We reviewed articles from Africa published into four databases namely: MEDLINE (PubMed), Google Scholar, Cochrane Library and Scientific Research Publishing from 2010 to 2019.

Results: We screened titles and abstracts of 2070 studies of which 311 were selected for full content evaluation and 199 studies were considered. Selected articles varied substantially on the basis of the topics they addressed covering the field of influenza surveillance $(n=80)$; influenza risk factors and co-morbidities $(n=15)$; influenza burden $(n=37)$; influenza vaccination $(\mathrm{n}=40)$; influenza and other respiratory pathogens $(\mathrm{n}=22)$ and influenza diagnosis $(\mathrm{n}=5)$.

Conclusion: Significant progress has been made since the last pandemic in understanding the influenza epidemiology in Africa. However, efforts still remain for most countries to have sufficient data to allow countries to prioritize strategies for influenza prevention and control.
\end{abstract}

Keywords: Influenza; epidemiology; review; Africa; post pandemic.

DOI: https://dx.doi.org/10.4314/ahs.v20i4.5

Cite as: Lagare A, Rajatonirina S, Testa J, Mamadou S. The epidemiology of seasonal influenza after the 2009 influenza pandemic in Africa: a systematic review. Afri Health Sci. 2020;20(4):1514-36. bttps:// dx.doi.org/ 10.4314 / abs.v20i4.5

\section{Introduction}

Globally, influenza virus infections result in substantial morbidity, mortality and economic losses every year ${ }^{1-3}$. Approximately $10-20 \%$ of the world's population are infected with seasonal influenza virus annually, of which 3-5 million are severe cases ${ }^{4,5}$. Young children, pregnant women, the elderly, and persons with underlying medical conditions are at increased risk of influenza-associated illness ${ }^{6,7}$. Recent estimates indicated that 291,243-645,832 seasonal influenza-associated respiratory deaths occur annually globally with the highest mortaity rates observed in sub-Saharan Africa

\author{
Corresponding author: \\ Adamou Lagare, \\ Centre de Recherche Médicale et Sanitaire \\ (CERMES)634 Boulevard de la Nation YN034, \\ Niamey, Niger BP: 10887 \\ Tel: +227207520 40 / 45 \\ Cell: +22796973739 \\ Fax: +22720753180 \\ Email: adamsyn03@gmail.com
}

$(2 \cdot 8-16 \cdot 5$ per 100000 individuals) compared to other Regions ${ }^{8}$.

The epidemiology of influenza is well-documented in high-income countries, however in Africa fewer data are available ${ }^{6,7,9}$. A literature review on influenza in sub-Saharan Africa conducted between 1980 and 2009 found that most countries in this region did not have sufficient data on inflenza to prioritize strategies for influenza prevention and control ${ }^{10}$.

Nonetheless, after the emergence of the pandemic influenza virus $\mathrm{A}(\mathrm{H} 1 \mathrm{~N} 1)$ in $2009 \mathrm{~A}(\mathrm{H} 1 \mathrm{~N} 1) \mathrm{pdm} 09$ concerted efforts from the World Health Organization (WHO) Member States have led to significant increases in trained personnel and equipped laboratories leading to influenza surveillance expansion, including the capacities to detect and monitor influenza viruses global$1 y^{5,11}$. As a result, several international institutions and governments, in partnership with African countries, invested in the development of epidemiologic and laboratory influenza surveillance capacity on the continent and the African Network of Influenza Surveillance and 
Epidemiology (ANISE) was formed in $2009^{6}$. In addition, in 2011, WHO initiated a project "Strengthening Influenza Sentinel Surveillance in Africa (SISA)" in 8 African countries to help improve influenza sentinel surveillance, including both epidemiological and virological data collection, and to develop routine national, regional and international reporting mechanisms ${ }^{12}$. Since 2009 over 30 countries in Africa have established or expanded influenza surveillance systems ${ }^{13-21}$ and 14 countries have received National Influenza Center (NIC) recognition from the $\mathrm{WHO}^{7}$. Analysis from a regional study in Africa on influenza surveillance revealed that the number of African countries reporting data to WHO's global platform FluNet increased substantially after the pandemic ${ }^{6}$.

The burden of influenza has been studied almost exclusively in developed settings, but influenza may have a different pattern in lesser resourced settings such as Africa. It has been suggested that the burden of influenza-associated illness, may be higher in Africa than in other regions due to socio-economic factors, high prevalence of underlying medical conditions, including a heavy burden of HIV and tuberculosis infections, and poor access to care ${ }^{6,22}$. Nonetheless, policies and interventions to mitigate the impact of influenza-associated illness in Africa are lacking ${ }^{23}$.

In this study, we aim to assess the state of knowledge gathered from seasonal influenza epidemiology in Africa and identify potential data gaps for policy formulation following the 2009 pandemic.

\section{Methods}

\section{Literature search Strategy OR data source}

In this retrospective inventory, we searched for articles published between $1^{\text {st }}$ January 2010 to $31^{\text {st }}$ December 2019 using four data sources including the U.S. National Library of Medicine (PubMed), Google Scholar, Cochrane Library and Scientific Research Publishing. We considered studies from all African countries, including those belonging to the WHO Regional Office for Africa (AFRO) and WHO Regional Office for the Eastern Mediterranean (EMRO) including Morocco, Tunisia, Egypt, Sudan, Libya and Djibouti ${ }^{24}$. However, we did not take in account datarom la Reunion and Mayotte since these two countries are administratively part of the France overseas departments and their data were usually included in national data from France until very recently.

Consistently with the systematic review conducted during 1980-2009 ${ }^{10}$, we searched for the following terms: ("influenza" AND "Africa") OR ("acute respiratory in- fection" AND "Africa”) OR ("influenza" AND “each individual African country").

\section{Study selection}

We considered studies on influenza surveillance, influenza risk factors and co-morbidities, influenza burden, influenza vaccination or treatment, influenza and other respiratory pathogens, and influenza diagnostic techniques. We searched references of identified studies for additional studies, and we reviewed abstracts and titles of selected studies if they included some aspects of influenza epidemiology consistent with the inclusion criteria mentioned above.

We excluded from this review: studies published before 2010, studies conducted exclusively before 2010 (although published after 2010), studies not presenting data from African countries only, studies reporting a review of literature, studies reporting data on avian influenza only and studies published in other languages than English and French.

\section{Data abstraction}

AL conducted the search to screen and select papers of interest from the four databases and entered the data into a structured Excel database. Considered abstracts from selected papers were reviewed by SR and JT for validation. SR, JT, SM approved all processes for data abstraction and analysis. Any disagreements were resolved after discussion.

For quality assessment of the system, 20\% $(n=22)$ of randomly selected articles not considered and all the considered articles $(n=199)$ were reviewed by SR to check for abstraction accuracy and full content evaluation.

\section{Data analysis}

Statistical data analysis was conducted using Excel software. We did a qualitative synthesis of considered articles and grouped the findings of the selected articles according to pre-determined categories. Articles reporting data on influenza circulation, and seasonality including regional or sub regional studies were grouped under the influenza surveillance category. Articles dealing with risk factors associated severe acute respiratory infections (SARI) hospitalization or death and influenza associated with other diseases were grouped uner influenza risk factors and co-morbidities. Articles reporting data on hospitalization and/or mortality rates, incidence and national burden were grouped under the influenza disease burden category. Articles reporting data on the association of influenza and other respiratory patho- 
gens, including viruses and bacteria, were grouped under the influenza and other respiratory pathogens category. The influenza vaccination category consisted of articles reporting studies on vaccine coverage, vaccine efficacy and also knowledge, attitude and practice (KAP) on influenza. Articles reporting studies on influenza diagnostic techniques and assessments were grouped under the influenza diagnostic category (Figure 1).

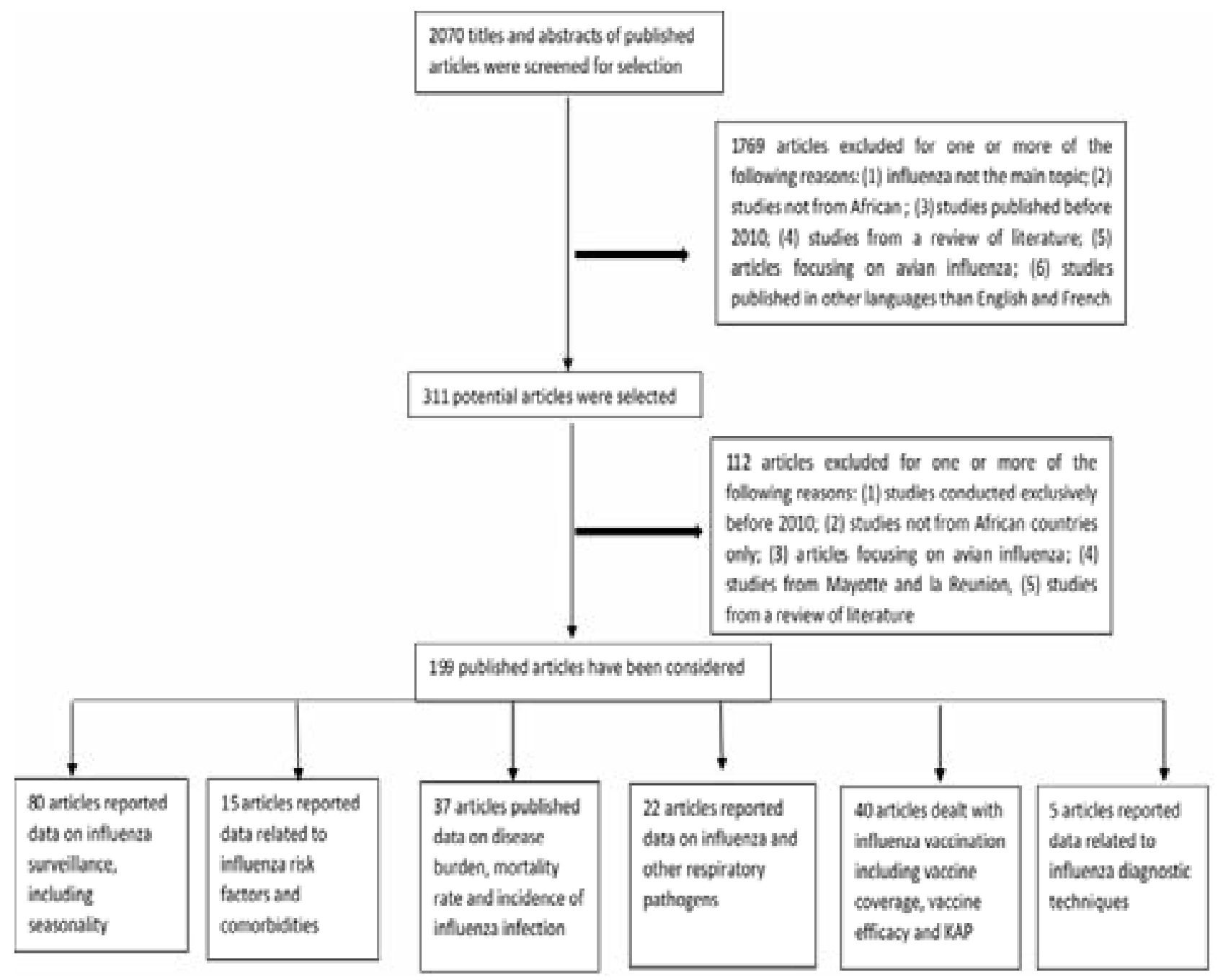

Figure 1: Study design chart

\section{Results}

\section{Current status of knowledge}

We screened the titles and abstracts of 2070 studies out of which 311 were selected for full content evaluation and of those, 199 studies were considered for analysis. All considered articles were validated according to quality assessment of inclusion criteria and full content evaluation. Selected articles varied substantially on the basis of the topics they addressed: 80 articles reported results of influenza surveillance $13-15,17-20,25-91$ including 5 regional or sub-regional studies $6,7,92-94 ; 15$ articles addressed topics on influenza risk factors and co-morbidities 95-109; 37 articles reported findings on burden of influenza 9, 19, 110-143 including 1 regional article 144; 22 articles reported data on influenza and respiratory pathogens $145-167 ; 40$ articles reported data on influenza vaccination 168-194 including 2 regional studies 195, 196 and 13 KAP 183, 196-207; and 5 articles reported data on influenza diagnostic techniques 208-212. Overall, 30 countries in Africa have articles published on different aspects of influenza epidemiology (Table I). 
Table 1: Distribution of published articles by regions and countries in Africa, 2010-2019

\begin{tabular}{|c|c|c|c|c|c|c|c|}
\hline \multirow[b]{2}{*}{ Regions / Countries } & \multicolumn{7}{|c|}{ Article types $(\mathrm{N}=199)$} \\
\hline & $\begin{array}{l}\text { INF } \\
\text { surveillance } \\
(\mathrm{N}=80)\end{array}$ & $\begin{array}{l}\text { INF risk factor and } \\
\text { comorbities } \\
(\mathrm{N}=15)\end{array}$ & $\begin{array}{l}\text { INF burden } \\
(\mathrm{N}=37)\end{array}$ & $\begin{array}{c}\text { INF and other } \\
\text { Pathogens }(\mathrm{N}=22)\end{array}$ & $\begin{array}{c}\text { INF } \\
\begin{array}{c}\text { vaccination } \\
(\mathrm{N}=40)\end{array} \\
\end{array}$ & $\begin{array}{l}\text { INF diagnostic } \\
(\mathrm{N}=5)\end{array}$ & Total \\
\hline \multicolumn{8}{|l|}{ North Africa } \\
\hline Algeria & 1 & & & & & & 1 \\
\hline Egypt & 2 & 1 & 4 & 2 & & & 9 \\
\hline Morocco & 3 & 1 & & & 1 & & 5 \\
\hline Tunisia & 5 & 1 & 2 & & 1 & 1 & 10 \\
\hline \multicolumn{8}{|l|}{ West Africa } \\
\hline Burkina Faso & 3 & & & 1 & & & 4 \\
\hline Ivory Coast & 2 & & & & 2 & & 4 \\
\hline Gambia & & & & 1 & 1 & & 2 \\
\hline Ghana & 3 & & 2 & 1 & & & 6 \\
\hline Mali & 1 & & & 1 & 2 & & 4 \\
\hline Niger & 2 & & & 1 & & & 3 \\
\hline Nigeria & 1 & & & & 1 & & 2 \\
\hline Senegal & 2 & & 1 & 2 & 2 & & 7 \\
\hline Sierra Leone & 1 & & & & & & 1 \\
\hline Togo & 1 & & & & & & 1 \\
\hline \multicolumn{8}{|l|}{ Central Africa } \\
\hline Cameroon & 6 & & & 1 & & 1 & 8 \\
\hline Gabon & 1 & & 1 & 1 & & & 3 \\
\hline CAR* & 1 & & & & & & 1 \\
\hline DRC* & 3 & & 1 & & & & 3 \\
\hline \multicolumn{8}{|l|}{ East Africa } \\
\hline Ethiopia & 2 & & & & 1 & & 3 \\
\hline Kenya & 10 & 1 & 6 & 2 & 7 & 2 & 28 \\
\hline Madagascar & 4 & & 2 & 2 & & & 8 \\
\hline Malawi & 1 & 2 & 1 & & 3 & & 7 \\
\hline Mozambique & 2 & & & 1 & & & 3 \\
\hline Uganda & 6 & & 1 & & & & 7 \\
\hline Tanzania & 1 & & & & & & 1 \\
\hline Rwanda & 1 & & 1 & & & & 2 \\
\hline Sudan & & & & 1 & & & 1 \\
\hline \multicolumn{8}{|l|}{ Southern Africa } \\
\hline Angola & 1 & & & & & & 1 \\
\hline South Africa & 9 & 9 & 13 & 5 & 17 & 1 & 55 \\
\hline Zambia & & & 1 & & & & 1 \\
\hline \multicolumn{8}{|l|}{ Sub-regional studies } \\
\hline & 5 & & 1 & & 2 & & 8 \\
\hline
\end{tabular}

African countries were grouped according to UNICEF classifications for The State of Africa's Children 2008 based on United Nations regional groupings (https://www.unicef.org/childsurvival/files/SOAC. pdf). Thus, 30 countries from various regions have published influenza data based on our search, with South
Africa and Kenya being most represented. The number and types of published articles show a relative increase across the years. From 2010 to 2014 most articles addressed influenza surveillance data, while since 2015 predominant article types reported data on disease burden (including mortality and incidence) and vaccination (Figure 2). 


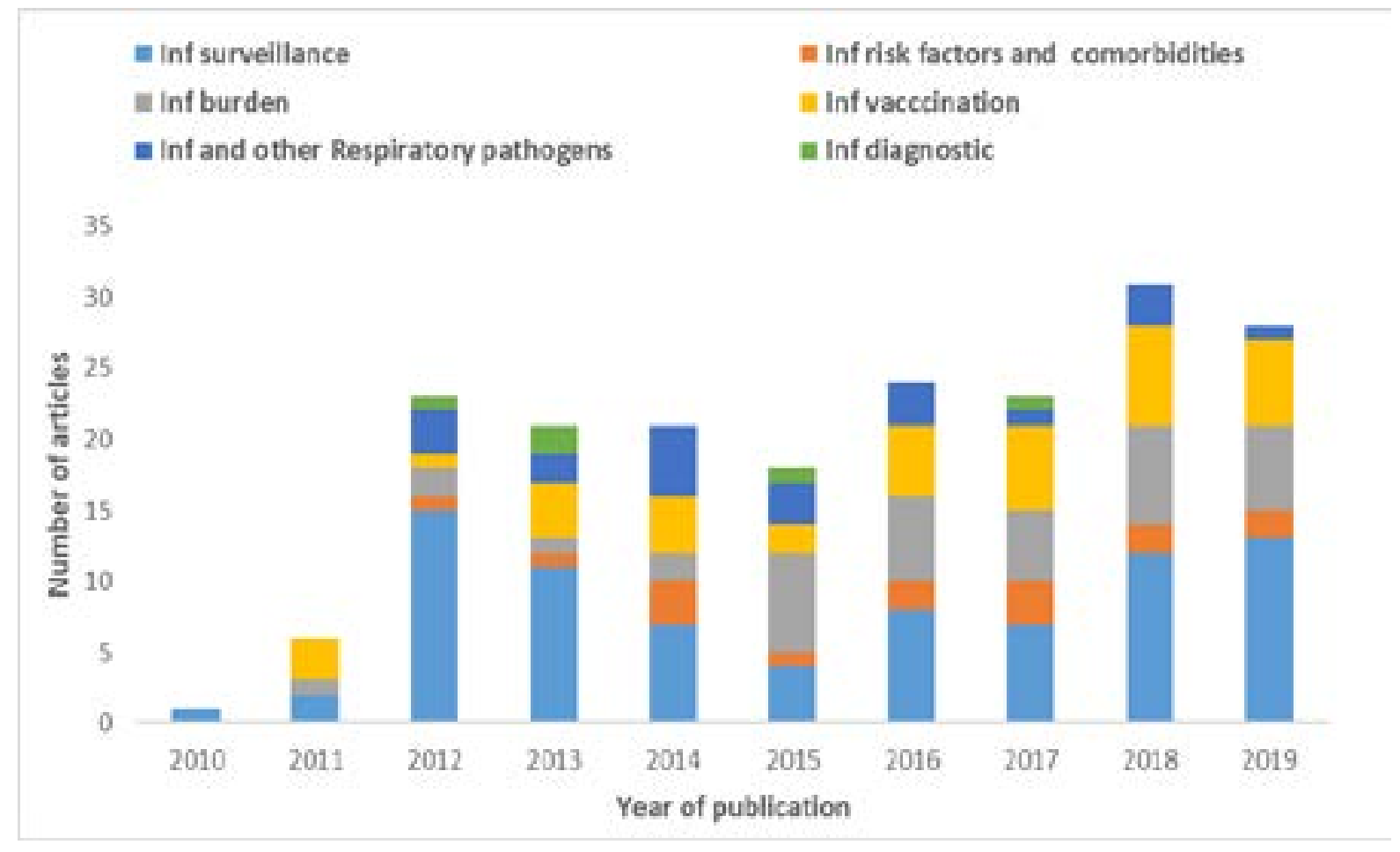

Figure 2: Number and type of published articles per year in Africa, 2010-2019

\section{Influenza surveillance}

A total of 27 countries published data on influenza surveillance from 2010-2019. These data covered aspects of influenza detection and seasonality. 21 countries reported influenza surveillance data among inpatients with severe acute respiratory infection (SARI) and outpatients with influenza-like-illness (ILI) ${ }^{6,13,19,26,27,30,32,33,}$ 36, 37, 40, 45, 46, 51, 55, 61, 64, 69, 70, 72; whereas Gabon, Togo, Burkina Faso, Central Africa Republic and Uganda reported influenza surveillance data among outpatients with ILI only ${ }^{14,17,18,60,73,154}$.

Globally, the case definition used in most surveillance systems was consistent with that of WHO for influenza-like illness (defined as an acute respiratory infection with measured fever of $\geq 38^{\circ} \mathrm{C}$, and cough, with onset within the last 7 or 10 days), or severe acute respiratory infection (defined as an acute respiratory infection with history of fever or measured fever of $\geq 38^{\circ} \mathrm{C}$, and cough, with onset within the last 7 or 10 days, and requiring hospitalization) ${ }^{18,26,28,30,32,49}$. These case defi- nitions were also reported by two regional studies ${ }^{6,94}$. However, other systems used stratified SARI case definition according to various age particularly in younger children ${ }^{28,96}$. Other systems also used modified WHO case definition mainly for severe cases based on the WHO Integrated Management of Childhood Illness guidelines for pneumonia or severe pneumonia $25,27,33$, 34, 39, 96 (Table II). A study from South Africa evaluated the performance of case definition of severe influenza among HIV infected and non-infected patients and found the sensitivity and specificity of the WHO post2014 case definition more suitable than the previous case definitions irrespective of HIV infection status ${ }^{85}$. Three studies reported results of the evaluation of influenza surveillance systems and found that the influenza surveillance system provided pertinent evidence for public health interventions related to influenza situational awareness although important parameters such as case definition and timely reporting of data should be strengthen to promote prevention interventions especially among the most vulnerable groups ${ }^{28,81,89}$. 
Table II : Summary of influenza surveillance data in selected Africa countries from 2010-2019

\begin{tabular}{|c|c|c|c|c|c|c|c|c|c|c|c|}
\hline Country & Author & Study period & $\begin{array}{l}\text { Enrolled } \\
\text { patients }\end{array}$ & $\begin{array}{l}\text { ILI detection } \\
\text { rate }(\%)\end{array}$ & $\begin{array}{l}\text { SARI detection } \\
\text { rate }(\%)\end{array}$ & $\begin{array}{l}\text { Total detection } \\
\text { rate }(\%)\end{array}$ & $\begin{array}{l}\text { Number of } \\
\text { sites }\end{array}$ & Case definition & $\begin{array}{l}\text { Method of } \\
\text { sampling }\end{array}$ & $\begin{array}{l}\text { Method of } \\
\text { detection }\end{array}$ & Protocol used \\
\hline Ethiopia & Ayele, et al. & 2008-10 & 176 & 12 & 4 & 7 & 5 & WHO & $\mathrm{NP}$ & $\mathrm{qPCR}$ & $\mathrm{CDC}$ \\
\hline Ethiopia & Woyessa, et al. & $2009-15$ & 4799 & $27 \%$ & $3 \%$ & 20.6 & 7 & WHO & $\mathrm{NP} / \mathrm{OP}$ & $q P C R$ & $\operatorname{CDC}$ \\
\hline Angola & Cardoso, et al. & 2009-11 & 691 & 5 & 6 & 6 & 1 & WHO & $\mathrm{NP} / \mathrm{OP}$ & $q P C R$ & $\operatorname{CDC}$ \\
\hline South Africa & Cohen, et al. & $2009-12$ & 16,005 & - & 8 & 8 & SSP & WHO modified & $\mathrm{NP} / \mathrm{OP}$ & $q P C R$ & $\operatorname{CDC}$ \\
\hline South Africa & Seleka, et al. & 2005-14 & 39,804 & 40.2 & 7.9 & 22 & VW/SSP/ILI & WHO modified & $\mathrm{NP} / \mathrm{OP}$ & qPCR & $\operatorname{CDC}$ \\
\hline Uganda & Cumming, et al. & 2010-15 & 10,142 & 12.8 & 8.5 & 11.2 & 12 & WHO & $\mathrm{NP} / \mathrm{OP}$ & qPCR & $\operatorname{CDC}$ \\
\hline Uganda & Wabwire, et al. & 2008-14 & 6,628 & 10.4 & - & 10.4 & 5 & WHO modified & $\mathrm{NP} / \mathrm{OP}$ & $\mathrm{qPCR}$ & $\operatorname{CDC}$ \\
\hline Nigeria & Dalhatu, et al. & $2009-10$ & 2,841 & 8 & 5 & 7.7 & 4 & WHO & $\mathrm{NP} / \mathrm{OP}$ & qPCR & $\operatorname{CDC}$ \\
\hline Kenya & Emukule, et al. & $2007-13$ & 55,192 & 16.3 & 8.8 & 12.2 & 12 & WHO modified & $\mathrm{NP} / \mathrm{OP}$ & $q P C R$ & $\operatorname{CDC}$ \\
\hline Kenya & Katz, et al. & 2007-13 & 38,775 & 14.6 & 9.6 & 11.4 & 11 & WHO modified & $\mathrm{NP} / \mathrm{OP}$ & qPCR & $C D C$ \\
\hline Kenya & Onyango, et al. & $2007-10$ & 2002 & 3.9 & 4.7 & 4.9 & 1 & WHO modified & NP & $\mathrm{qPCR}$ & Lassaniére \\
\hline Niger & Halima, et al. & $2009-13$ & 2,128 & 12 & 6 & 9.4 & 8 & WHO & $\mathrm{NP}$ & qPCR & $\operatorname{CDC}$ \\
\hline Ghana & Jones, et al. & $2010-13$ & 1,273 & 6 & 8 & 7 & 3 & WHO modified & $\mathrm{NP}$ & $q P C R$ & $\operatorname{CDC}$ \\
\hline Ivory Coast & Kadjo, et al. & $2003-10$ & 5,074 & $19 \%$ & - & $19 \%$ & 26 & $\operatorname{CDC}$ & NP & qPCR/culture & Cambodge \\
\hline Gabon & Lekana, et al. & 2009-11 & 966 & 13.6 & - & 13.6 & 4 & WHO & NP & $q P C R$ & - \\
\hline CAR & Manirakiza, et al. & 2010-15 & 5,385 & 8.4 & - & 8.4 & 2 & WHO & $\mathrm{NP} / \mathrm{OP}$ & $q P C R / P C R$ & - \\
\hline Tanzania & Mmbaga, et al. & $2008-10$ & 1,794 & 8.5 & 7.3 & 8 & 5 & WHO modified & $\mathrm{NP} / \mathrm{OP}$ & qPCR & $\operatorname{CDC}$ \\
\hline Tunisia & El Moussi, et al. & 2008-11 & 7,77 & - & - & 50.8 & 268 & WHO & $\mathrm{NP} / \mathrm{OP}$ & qPCR & Abott \\
\hline Madagascar & Orelle, et al. & $2009-10$ & 2,303 & - & - & 49.8 & 20 & WHO & $\mathrm{NP} / \mathrm{OP}$ & qPCR & $\operatorname{CDC}$ \\
\hline Madagascar & Rajatonirina, et al. & $2009-10$ & 750 & 33.2 & - & 33.2 & 24 & WHO & $\mathrm{NP} / \mathrm{OP}$ & qPCR & $\operatorname{CDC}$ \\
\hline Madagascar & Rakotoarisoa, et al. & $2009-14$ & 9192 & 38.9 & - & 39.9 & 12 & WHO & $\mathrm{NP} / \mathrm{OP}$ & qPCR & $\operatorname{CDC}$ \\
\hline Malawi & Ho, et al. & $2011-13$ & 1126 & - & 14.5 & 14.5 & 1 & WHO Modified & $\mathrm{NP}$ & $\mathrm{qPCR}$ & $\operatorname{CDC}$ \\
\hline Mozambique & Nguenha, et al. & $2014-16$ & 1997 & - & 3.9 & 3.9 & 2 & WHO & $\mathrm{NP} / \mathrm{OP}$ & qPCR & $\operatorname{CDC}$ \\
\hline Burkina & Tarnagda, et al. & $2010-11$ & 881 & 6.6 & - & 6.6 & 6 & WHO & $O P$ & $q P C R$ & $\operatorname{CDC}$ \\
\hline Burkina & Sagna, et al. & 2013-15 & 1392 & 14.9 & - & 14.9 & 2 & WHO & $O P$ & qPCR & $\operatorname{CDC}$ \\
\hline Marocco & Rhaffouli, et al. & 2009-11 & 1,183 & 31 & - & 31 & - & WHO modified & NP & $\mathrm{qPCR}$ & Roche \\
\hline Rwanda & Wane, et al. & $2009-10$ & 2,045 & 14 & 12 & 26 & 6 & WHO & $\mathrm{NP} / \mathrm{OP}$ & $q P C R$ & $\operatorname{CDC}$ \\
\hline Cameroon & Monamele, et al. & $2009-15$ & 5,216 & - & - & 22.2 & 5 & WHO & NP & qPCR & $C D C$ \\
\hline DRC & Muyembe, et al. & 2009-11 & 4,156 & 20 & 16 & 15 & 5 & WHO & $\mathrm{NP} / \mathrm{OP}$ & qPCR & $\mathrm{CDC}$ \\
\hline DRC & Kavubga, et al. & 2015 & 2376 & - & - & 9.1 & 5 & WHO & $\mathrm{NP} / \mathrm{OP}$ & $q P C R$ & $C D C$ \\
\hline Togo & Maman, et al. & $2010-12$ & 955 & 24.7 & - & 24.7 & 2 & WHO & $\mathrm{NP} / \mathrm{OP}$ & $\mathrm{QPCR}$ & $\mathrm{CDC}$ \\
\hline
\end{tabular}

Influenza surveillance in many African countries was dominated largely by pediatric inclusion of children $<$ 5 years although it aims to target all age categories ${ }^{6,14}$, $18,19,27,30,34,39,98$. In these systems, the high influenza detection rate was therefore due to infections in this age group ${ }^{14,18,34,39}$, although in a few countries the highest influenza positivity rate was observed among children 5-14 years and older adults ${ }^{17,25,27,32,53}$.

The rate of detection of influenza viruses varied considerably according to countries geographical location. It has been reported to be higher in temperate countries ranging from 33\% to 50\% in Madagascar, Morocco and

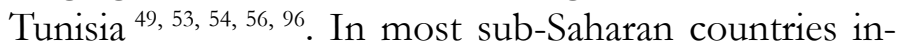
fluenza detection rate seemed to be relatively low ranging from $6 \%$ to $10 \%$ in Burkina Faso, Niger, Nigeria, Ghana, Republic of Central Africa, Angola, Tanzania $14,18,30,33,36,45,213$. However, other countries have reported influenza detection rate ranging from $10 \%$ to $26 \%$ including Kenya, South Africa, Senegal, RDC, Gabon, Uganda, Rwanda and Ethiopia ${ }^{13,15,19,32,42,58,62,77 .}$
Importantly, in most countries, influenza was more de-

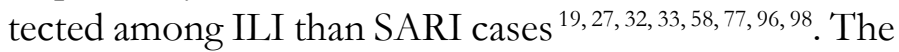
lowest influenza detection rate among ILI was 3.9\% reported by Onyango et al. in Kenya ${ }^{52}$ while the highest rate was $40.2 \%$ reported by Seleka et al. in South Africa ${ }^{58}$. Influenza seemed to be less detected among SARI cases ranging from $4 \%$ to $12 \%{ }^{27,31,62}$, although studies from Angola, Ghana and Kenya reported a higher rate of detection of influenza SARI compared to ILI cases 30, 36, 52 (Table II). A study from Cameroon reported influenza $\mathrm{C}$ virus among hospitalized patients apart from seasonal influenza types A and B, although on limited proportion $^{86}$.

Influenza testing was conducted on either nasopharyngeal and or oropharyngeal specimens collected from persons presenting for medical care at participating surveillance sentinels sites ${ }^{14,16,17,27,28,32,39,48,81,89,92,96 .}$ Most countries were applying a sampling restriction 
number for SARI and/or ILI at up to 5 cases sampled per week ${ }^{14,17,18,34}$, however in other systems, the sampling restriction was only applicable to ILI cases while all SARI cases were collected routinely ${ }^{27,28,33,39}$. Laboratory confirmation techniques were based on molecular detection by realtime reverse transcription polymerase

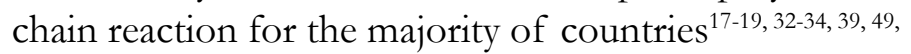
${ }^{214}$. However, countries with national influenza centers used culture and sequencing in addition to the molecular method ${ }^{48,71,75,82,84,96}$ (Table II).

The seasonality of influenza has been described in many countries and varied considerably. In temperate countries including South Africa, Egypt, Morocco and Tunisia influenza circulation showed regular patterns with one peak of detection during the winter which corresponds to May-September in South Africa ${ }^{28}$ similar to other temperate southern hemisphere patterns, and November to April in Egypt, Morocco and Tuni$\mathrm{sia}^{49,64,96}$ similar to temperate northern hemisphere patterns. This has also been described in a regional study reporting the seasonalitof influenza in Africa ${ }^{6}$. Influenza activity varied considerably in tropical countries and demonstrated different patterns with double peaks of

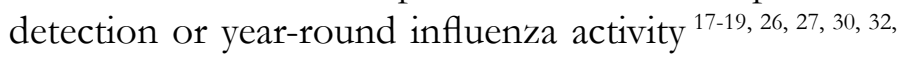
$33,39,51,213$. This has also been reported in two regional studies ${ }^{6,7}$.

\section{Influenza risk factors and co-morbidities}

Although data on risk factors for influenza are key to guide targeted influenza vaccination, few studies have addressed topics on the risk factors for influenza ${ }^{95-99}$. Results from these studies reported that underlying medical conditions such as HIV, tuberculosis, diabetes, chronic respiratory diseases, pregnancy and patient's age contribute strongly to influenza associated hospitalization or death. In a case population study between 2009 to 2012 in South Africa, Abandom et al. showed that risk factors for influenza associated SARI hospitalization included history of smoking case-population ratio (CPR) 3.82, HIV infection (CPR 3.61), asthma (CPR 2.45), history of hospital admission in the past 12 months (CPR 2.07), and tuberculosis (CPR 1.85) ${ }^{95}$. Tempia et al. using multivariate analysis on surveillance data from 2012 to 2015 in South Africa reported Streptococcus pneumoniae colonization density adjusted odds ratio (aOR) 4.8, malnutrition (aOR, 2.4), prematurity (aOR, 4.8), diabetes (aOR, 7.1), chronic lung diseases (aOR, 10.7), chronic heart diseases (aOR, 9.6), obesity (aOR, 21.3), mine working (aOR,13.8) and pregnancy (aOR, 12.5) as contributing factors for influenza-associated hospitalization ${ }^{98}$. Both studies also found an in- creased risk of hospitalization in those $\leq 5$ years of age (CPR 3.07) and among those 35 years of age and above (CPR 1.23). Moreover, Barakat et al. in Morocco found that influenza cases associated with hypertension (aOR, 28.2), neurological disorders (aOR), obesity (aOR, 7.1), as well as pregnancy $(\mathrm{aOR}, 2.5)$ were at increased risk of death ${ }^{96}$. Furthermore, Bouneb et al. in Tunisia using logical regression reported that acute respiratory distress syndrome (ARDS) $(\mathrm{OR}=27$; 95\%CI: 3.62203.78) was the only factor significantly associated with severe outcomes of influenza cases ${ }^{99}$.

Influenza associated co-morbidities have been studied nine articles from 3 countries ${ }^{101-105,107-109,134,215}$. In two studies on influenza associated respiratory infections in a high HIV Prevalence Setting, Cohen et al. in South Africa found that $44 \%$ of patients who tested positive for influenza were also infected with HIV while Ho et al. in Malawi reported a prevalence of $69.6 \%$, therefore supporting the evidence that HIV is an important risk factor for influenza-associated ILI and SARI ${ }^{100,}{ }^{102}$. In other studies, Peterson et al. found that HIV greatly increased the risk of influenza virus-associated SARI in children and von Mollendorf et al. show a potential difference in influenza virus shedding by CD4 count with individuals with lower counts shedding for longer ${ }^{103,105}$. Moreover, in study on household transmission of inflenza from HIV-infected and HIV-uninfected Individuals in South Africa, Cohen et al. found the increased infectiousness of HIV-infected individuals is likely not an important driver of community influenza transmission $^{108}$. Three studies from South Africa reported high correlations between influenza and invasive pneumonia disease or tuberculosis and that tuberculosis influenza co-infection was associated with increased risk of death compared to tuberculosis single infection ${ }^{101,109,215 .}$

\section{Influenza burden}

Overall, 37 articles from 14 countries 9, 82, 110-124, 128-131, 133, 135-137, 139-143, 216, 217 including 1 sub-regional paper ${ }^{144}$ have reported data on influenza burden, influenza associated mortality, case fatality rate and incidence. Seven papers have reported data on mortality associated with influenza SARI cases 110-112, 116, 118, 120, 138, 139, 144. The estimated incidence of influenza-associated SARI deaths per 100,000 population was highest in children $<1$ year $(20.1,95 \%$ CI 12.1-31.3) and adults aged 45-64 years $(10.4,95 \%$ CI $8.4-12.9)$ in South Africa ${ }^{111}$ while in Egypt the SARI case fatality rates by influenza virus type were: $50 \% \mathrm{~A} / \mathrm{H} 5 \mathrm{~N} 1,17 \% \mathrm{INF} \mathrm{A}$ and $\mathrm{B}^{120}$. Also, Emukule et al. found the estimated mean annual rate of influenza associated pneumonia hospitalization was 34 
(95\% CI 23-48) per 100,000 persons among children in Uganda ${ }^{138}$.

Four articles reported data on mortality associated with influenza and RSV among SARI patients 110, 116, 139, 216. Cohen et al. found that seasonal influenza and RSV allcause mortality rates in South Africa were 23.0 (95\% CI 11.0-30.6) and 13.2 (95\% CI 6.4-33.8) per 100000 population annually ${ }^{110}$, while Emukule reported 14.1 (95\% CI 0.0--93.3) and 17.1 (95\% CI 0.0--111.5) per 100,000 person-years respectively for influenza and $\mathrm{RSV}^{116}$.

12 articles reported data on influenza national burden associated SARI hospitalization 9, 113, 119, 121, 123, 125, 127-130, $135,141,142$. These rates varied considerably, for example it was estimated at 21 (95\% CI 19-23) in Kenya 113, 34.7 (95\% CI 25.4-47.7) in Rwanda ${ }^{127}$ and 43.9 (95\% CI 30.7-57.1 ) in Zambia ${ }^{130}$. However, SARI hospitalization was found to be much higher in children $<5$ years from all the studies. The rates per 100,000 individuals were 135 in Ghana ${ }^{126}, 100$ in Kenya ${ }^{216,} 128$ in Madagascar $^{141}, 168$ in Rwanda ${ }^{127}, 156$ in South Africa ${ }^{100}$ and 187 in Zambia ${ }^{130}$.

Three studies have estimated rates of influenza-associated ILI and SARI among HIV-infected and HIV-uninfected patients and found influenza-associated SARI and or ILI incidence rate greater among HIV-infected individuals ${ }^{125,133,134}$. The overall attributable fraction for influenza virus detection to illness was $92.6 \%$ for ILI, $87.4 \%$ for SARI, and $86.2 \%$ for severe chronic respiratory illness (SCRI) in South Africa supporting the evidence that influenza viruses when detected in patients with ILI, SARI, or SCRI are likely attributable to illness ${ }^{134}$. A study from Tunisia estimated proportions of influenza-associated ILI at $3.16 \%$ in the total outpatient $\operatorname{load}^{131}$.

Five articles reported burden data from selected populations in different countries $114,115,124,126,132$. Three studies reported ILI incidence which was 9.9 (95\% CI 2.9-33.6) in children $<5$ years in Senegal 115 and 3,448 (95\% CI $3,727-3,898)$ in Ghana 126 among children $<5$ years. The other study reported incidence of 24 per 100 person-years among pregnant women in Malawi ${ }^{114}$. SARI hospitalization rates in a selected site were reported to be 44 cases per 100000 person-years (95\% CI 39-48) in Egypt $^{132}$ and 14.7 (95\% CI 9.1-22.2) in Kenya among persons $>5$ years ${ }^{124}$.

\section{Influenza and other respiratory pathogens}

A total of 22 papers from 13 countries have reported data on influenza and other respiratory pathogens including both viruses and bacteria ${ }^{145-167}$. From these, 13 studies reported data on respiratory pathogens among children $<5$ years with SARI $145,146,149,151,153,155,156,161,162$, ${ }^{165-167,218}$, while 9 studied reported data on respiratory pathogens among other age groups ${ }^{147,}, 148,150,152,157-160,163$. The detection of respiratory virus varied considerably. In most studies among children $<5$ years, respiratory syncytial virus was the predominating virus detected in a proportion of $14.1 \%$ in Ghana ${ }^{153}$ to $81 \%$ in Sudan ${ }^{48}$. However, other studies reported rhinovirus as the predominating virus detected in a proportion of $20.5 \%$ to $59.1 \%$ respectively ${ }^{151,155}$. Two studies also reported respiratory virus detection among ILI cases in children $<5$ years 154 and persons $>50$ years ${ }^{147}$. From these studies adenovirus was the predominant virus detected in a proportion of $17.5 \%$ and $22 \%$ respectively.

Besides viruses, bacterial pathogens were also reported in many studies as etiological agents of respiratory infections associated with influenza infection. Streptococcus pneumonia was the main bacterial pathogen detected $(>50 \%)$ and found mostly associated with respiratory viruses including influenza as coinfections ${ }^{145,149,165}$. Three studies reported that influenza was associated with pneumonia in children $<5$ years ${ }^{145,159,160}$.

\section{Influenza vaccination}

Influenza vaccine is rarely used in most African countries. However, a total of 40 articles from 12 countries have reported data on influenza vaccine including vac-

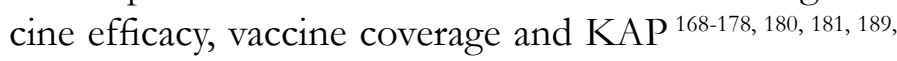
$190,192,194,219$. Vaccine effectiveness and safety was reported in 14 papers ${ }^{168,171,173-179,181,189,190}$. Three studies have reported the effectiveness of trivalent inactivated influenza vaccine in pregnant women, resulting in protecting their infants against influenza illness ${ }^{172,177,179}$. However, other studies reported moderate influenza vaccine effectiveness (VE) in preventing medically attended influenza-associated respiratory illnesses in Kenya ${ }^{171}$ and South Africa ${ }^{175,176}$. The results from two randomized studies, one from Senegal on live attenuated influenza vaccine against H1N1pdm09 181 and two from South Africa on influenza vaccine efficacy among HIV infected pregnant women reported effective protection among pregnant women and poor efficacy to protect their infants ${ }^{169,173}$.

A regional study on influenza vaccines and antiviral drug availability in Africa estimated a low coverage of the continent ${ }^{195}$. From this study, 19/31 (65\%) countries reported availability of antiviral drugs for the treatment of influenza while vaccine coverage ranged from $<0.5 \%$ to $2 \%$ of the population. However, a study from Kenya reported that $64 \%$ of health care personnel received monovalent influenza A (H1N1) pandemic 2009 
vaccine in $2010{ }^{178}$. Duque et al. reported that although the Northern and Southern hemisphere influenza vaccine formulations have been identical over recent years, the Southern Hemisphere formulation is most widely used in Africa despite its lower production worldwide 195.

The cost-effectiveness of influenza vaccine has been studied in a Malian paper which estimated the cost of maternal influenza immunization in pregnant woman and found that a maternal influenza immunization program in Mali would cost \$857 (95\% UI: \$188-\$2358) per disability-adjusted life year (DALY) saved 180. In another study from South Africa, Biggerstaff et al. found the cost effectiveness of vaccinating the cohort of pregnant women with prioritization had lower societal cost compare to vaccination without prioritization $^{191}$.

Knowledge, attitude and practice (KAP) towards influenza vaccine pointed mainly to the level of education, socio-cultural conspiracy, media access, and logistical challenges as influencers of vaccine coverage in Afri$\mathrm{Ca}^{183,193,196-201,203,205-207}$. However, a survey among healthcare workers in Ivory Coast and Kenya revealed that most were willing to accept vaccination if they had adequate informaton on safety and efficacy ${ }^{202,204}$.

\section{Influenza diagnostic}

A total of 5 articles have evaluated diagnostic techniques for influenza detection ${ }^{157,208-211}$. Two studies from Tunisia and South Africa evaluated the use of multiplex rRT-PCR in the identification of respiratory viruses with a sensitivity $>90 \%$ and Specificity of $100 \%$ thus allowing effective and fast diagnosis of respiratory viral infections ${ }^{157,208}$. Feikin et al. found that serology, along with PCR, can maximize etiologic diagnosis in epidemiologic studies ${ }^{209}$. Other studies have evaluated the use of rapid influenza diagnostic tests compared to rRTPCR. Kenmoe et al. in Cameroon found a lower sensitivity $(29.4 \%)$ of the SD Bioline rapid antigen test ${ }^{210}$ while Ndegwa et al. in Kenya found acceptable sensitivity $(77.1 \%)$ for the Becton Dickinson Veritor ${ }^{\mathrm{TM}}$ System Flu $\mathrm{A}+\mathrm{B}$ rapid influenza diagnostic test (RIDT) ${ }^{211}$. Both studies concluded the advantage of using a rapid test for identification of influenza cases with regard to the high specificity $(100 \%)$ although recommending that negative results be confirmed by rRT-PCR.

\section{Discussion}

Previous reviews of seasonal influenza in Africa published in 2002 and 2010 reported paucity of influenza data before the 2009 pandemic $^{10,220}$. However, since then, significant progress have been made to address some of the critical deficits in knowledge about the epidemiology and burden of seasonal influenza in Africa ${ }^{7}$, 221.

From our search, 199 published articles from 30 countries have been recorded covering various aspects of influenza surveillance, influenza risk factors and co-morbidities, influenza burden, influenza vaccination, influenza diagnostics, influenza and coinfection with other respiratory pathogens. This significant increase shows the main advances made by the continent since the pandemic as compared to that reported by Gessner et al. from 1980 to $2009^{10}$. This important progress could be attributed to many interventions and supports from international institutions mainly WHO and CDC Atlanta towards building routine influenza surveillance systems in African countries ${ }^{6}$.

While many countries have published data on influenza surveillance system, only few countries have addressed influenza risk factors. Results of these studies clearly reported young and older age, pregnancy and underlying medical conditions such as HIV, obesity, asthma, malnutrition, chronic heart disease etc. as main factors contributing to influenza severity in Africa. These factors were similar in some extent to those reported by studies conducted in other continents, particularly in Europe and USA where influenza infection has been shown to be associated mostly with older age, pregnancy, underlying medical conditions and immune-deficiency ${ }^{222,223}$. Three studies reported that tuberculosis-influenza co-infection was associated with increased risk of death compared to tuberculosis single infection $101,109,215$. These findings were partly confirmed by the results of a recent study on the systematic review of the coinfection of influenza and tuberculosis which found pulmonary tuberculosis (PTB) to be a risk factor for influenza-associated hospitalization ${ }^{224}$.

Influenza transmission through various age groups and seasonality have been clearly identified in countries from temperate regions ${ }^{225,226}$, however in many African countries particularly in the sub Saharan region more data need to be gathered in order to define clearly the seasonal pattern of influenza infection ${ }^{6,7}$. In these systems, influenza detection was largely predominated by pediatric inclusion that is children $<5$ years ${ }^{14}, 17,18,45$, $127,165,227$ which limit the capacity to stratify the disease transmission through various age groups. In addition, the relatively low influenza detection rate reported in many countries could be explained by geographical conditions and level of influenza surveillance.

Before the 2009 pandemic, most countries in Africa lack data on influenza burden estimate, making it dif- 
ficult for policy-makers to decide on how to distribute limited resources ${ }^{228}$. Since 2010, nine countries including South Africa, Kenya, Madagascar, Ghana, Senegal, Egypt, Zambia, Rwanda and DRC have published national burden estimate data $110,111,113,115,119,121,127,130,135,137$, 216. From these studies, the estimated rates (per 100,000 population) of influenza-associated SARI hospitalization among children aged $<5$ years was 135 in Ghana ${ }^{126}$, 100 in Kenya ${ }^{216}, 128$ in Madagascar ${ }^{141}, 168$ in Rwanda ${ }^{127}, 156$ in South Africa ${ }^{100}$ and 187 in Zambia 130. These findings were concordant with those from a global estimate of influenza hospitalization associated respiratory infections among children $<5$ years from 1982 to 2012 which reported that Africa has the highest rate of influenza hospitalization estimated at 174 per $100,000^{229}$. Meanwhile, the estimated rates of influenza-associated ILI outpatient consultation per 100,000 population was 1205 in DRC ${ }^{135}, 895$ in Ghana ${ }^{126}, 720$ in Kenya ${ }^{230}$ and 1337 in South Africa ${ }^{231}$. These estimates were higher than those reported in a study in the USA ${ }^{232}$.

Although important progress has been made by some countries mainly South Africa, Kenya, Senegal and Madagascar efforts still remain for most countries to have sufficient data to allow prioritization of strategies for influenza prevention and control. In addition, there is also lack of influenza economic burden data for all the countries in Africa, although a recent study from South Africa found substantial economic burden of influenza-assciated illness from both a government and a societal perspective estimated at $\$ 270.5$ million annually ${ }^{142}$. These estimates were consistent with those reported in Bangladesh where the economic burden was estimated at $\$ 169$ million in $2010^{233}$; however lower than that reported from a study in USA which estimated average annual total economic burden of influenza to the healthcare system and society at $\$ 11.2$ billion ${ }^{234}$. Vaccination remains the most efficacious means of mitigating the harmful healthcare and social effects of influenza, however, this practice is not yet implemented in many countries due to behavioral consideration and vaccines costs $188,200,204$. Therefore, other control measures for prevention of seasonal influenza in the continent such as hygiene measures, use of personal protective equipment and self-quarantine could represent alternative methods (https://www.cdc.gov/flu/ prevent/actions-prevent-flu.htm). Influenza vaccines have been shown to be efficient in protecting against influenza infection. However, its coverage is still very low in Africa $(<2 \%)$ 195, compared to $75 \%$ in Europe (ECDC) and 81.1\% among children in US (CDC). Preg- nant women have a particularly high risk of illness and hospitalization from influenza. Two studies have reported effective protection of influenza vaccine among pregnant women and poor efficacy to protect their infants ${ }^{169,173}$. However, results from a recent review study found that vaccination in a later trimester could benefit both the mother and newborn ${ }^{235}$. Indeed, recent estimates of the cost per hospital day averted and the cost per year of life saved by influenza vaccination in South Africa recommended that pregnant women and HIV-infected persons to be prioritized for publicly funded influenza vaccination given available evidence on influenza-associated disease burden ${ }^{140}$.

This study presents two main limitations. First, we did not conduct meta-analysis of data which would have allowed qualitative and quantitative assessments using previous studies findings. Second, we only used free access online databases which could have slightly underestimated the number of published papers particularly from the northern African countries where many studies were reported into regional journal which were not indexed.

\section{Conclusion}

This literature review makes an important contribution to knowledge about the epidemiology of seasonal influenza in Africa and that much more is known about influenza in Africa since the last pandemic than ever before. The increase in influenza surveillance in the region and the availability of documented national data make it possible to show the variable contribution of influenza infection across the continent. Indeed, these observed advances in influenza surveillance improve the contribution of the continent to the global influenza surveillance network. Importantly, the development of strategies for planning and response based on achievements and lessons learned could be useful for countries in Africa to prepare for the next pandemic. However, sustainability of the surveillance systems is the main challenges in most countries as it relies almost exclusively on international supports. Therefore, national data on influenza disease burden could be useful for decision makers to assess the public health importance of influenza, to identify high risk groups and regions, to allocate resources efficiently, and to consider the cost-effectiveness of preventive strategies, such as vaccination.

\section{Acknowledgements}

We acknowledge the efforts of all cited authors whose works contributed to the development of this paper. 
We thank Dr Jane Getchell for English revision of the manuscript.

\section{Competing interests}

The authors declare no competing interest.

\section{Funding source}

This research did not receive any specific grant from funding agencies in the public, commercial, or not-forprofit sectors.

\section{Authors' contributions}

Conception and design of the study: AL, JT and SM.

Data abstraction: AL

Data abstraction validation: SR, JT and SM

Analysis and interpretation of data: AL, JT, SM

Quality assessment: SR

Drafting the manuscript: AL

Critical revision of the manuscript: SR, JT, SM

All authors have read and agreed to the final version of this manuscript.

\section{Reference}

1. Stiver HG: The threat and prospects for control of an influenza pandemic. Expert Rev Vacines 2004, 3(1):35-42.

2. Boktor SW, Hafner JW: Influenza. In: StatPearls. edn. Treasure Island (FL); 2017.

3. Stamboulian D, Bonvehi PE, Nacinovich FM, Cox N: Influenza. Infect Dis Clin North Am 2000, 14(1):141-166. 4. Liu XX, Li Y, Zhu Y, Zhang J, Li X, Zhao K, Hu M, Qin G, Wang XL: Seasonal pattern of influenza activity in a subtropical city, China, 2010-2015. Sci Rep 2017, 7(1):17534.

5. Sanicas M, Forleo E, Pozzi G, Diop D: A review of the surveillance systems of influenza in selected countries in the tropical region. Pan Afr Med J 2014, 19:121. 6. Radin JM, Katz MA, Tempia S, Talla Nzussouo N, Davis R, Duque J, Adedeji A, Adjabeng MJ, Ampofo WK, Ayele W et al: Influenza surveillance in 15 countries in Africa, 2006-2010. The Journal of Infectious Diseases 2012, 206 Suppl 1:S14-21.

7. Talla Nzussouo N, Duque J, Adedeji AA, Coulibaly D, Sow S, Tarnagda Z, Maman I, Lagare A, Makaya S, Elkory $\mathrm{MB}$ et al: Epidemiology of influenza in West Africa after the 2009 influenza A(H1N1) pandemic, 2010-2012. BMC Infectious Diseases 2017, 17(1):745.

8. Iuliano AD, Roguski KM, Chang HH, Muscatello DJ, Palekar R, Tempia S, Cohen C, Gran JM, Schanzer D, Cowling BJ et al: Estimates of global seasonal influenza-associated respiratory mortality: a modelling study. Lancet 2017.
9. Katz MA, Lebo E, Emukule G, Njuguna HN, Aura B, Cosmas L, Audi A, Junghae M, Waiboci LW, Olack $\mathrm{B}$ et al: Epidemiology, seasonality, and burden of influenza and influenza-like illness in urban and rural Kenya, 2007-2010. The Journal of Infectious Diseases2012, 206 Suppl 1:S53-60.

10. Gessner BD, Shindo N, Briand S: Seasonal influenza epidemiology in sub-Saharan Africa: a systematic review. The Lancet Infectious Diseases 2011, 11(3):223-235. 11. Ortiz JR, Sotomayor V, Uez OC, Oliva O, Bettels D, McCarron M, Bresee JS, Mounts AW: Strategy to enhance influenza surveillance worldwide. Emerging Infectious Diseases 2009, 15(8):1271-1278.

12. Steffen C, Debellut F, Gessner BD, Kasolo FC, Yahaya AA, Ayebazibwe N, Bassong O, Cardoso Y, Kebede $S$, Manoncourt $S$ et al: Improving influenza surveillance in sub-Saharan Africa. Bulletin of the World Health Organization 2012, 90(4):301-305.

13. Muyembe Tamfum JJ, Nkwembe E, Bi Shamamba SK, Bankoshi F, Ilunga BK, Katz KA, Cohen AL, Kabamba J, Wemankoy EO: Sentinel surveillance for influenza-like illness, severe acute respiratory illness, and laboratory-confirmed influenza in Kinshasa, Democratic Republic of Congo, 2009-2011. The Journal of Infectious Diseases 2012, 206 Suppl 1:S36-40.

14. Tarnagda Z, Yougbare I, Ilboudo AK, Kagone T, Sanou AM, Cisse A, Medah I, Yelbeogo D, Nzussouo NT: Sentinel surveillance of influenza in Burkina Faso: identification of circulating strains during 2010-2012. Influenza and other respiratory viruses 2014, 8(5):524-529.

15. Thiam D, Niang M, Dia N, Sarr FD, Goudiab D, Senghor ML, Kiori D, Faye T, Espie E, Ba IO et al: Influenza sentinel surveillance network improvement in Senegal and results. Bull Soc Pathol Exot 2015, 108(1):2124.

16. Mainassara HB, Lagare A, Tempia S, Sidiki A, Issaka B, Abdou Sidikou B, Oukem-Boyer OO: Influenza Sentinel Surveillance among Patients with Influenza-Like-Illness and Severe Acute Respiratory Illness within the Framework of the National Reference Laboratory, Niger, 2009-2013. PLoS One 2015, 10(7):e0133178.

17. Maman I, Badziklou K, Landoh ED, Halatoko AW, Nzussouo TN, Defang GN, Tamekloe TA, Kennedy PJ, Thelma W, Kossi $\mathrm{K}$ et al: Implementation of influenza-like illness sentinel surveillance in Togo. BMC Public Health 2014, 14:981.

18. Manirakiza A, Ketta MB, Vickos U, Komoyo GF, Garba-Ouangole S, Bangue C, Djimbele E, Pasotti O, Kanga E, Mboufoungou EN et al: Sentinel surveillance of influenza-like illness in the Central African Republic, 2010-2015. Arch Public Health 2017, 75:61. 
19. Emukule GO, Mott JA, Spreeuwenberg P, Viboud C, Commanday A, Muthoka P, Munywoki PK, Nokes DJ, van der Velden K, Paget JW: Influenza activity in Kenya, 2007-2013: timing, association with climatic factors, and implications for vaccination campaigns. Influenza and other respiratory viruses 2016, 10(5):375-385.

20. Cummings MJ, Bakamutumaho B, Yang W, Wamala JF, Kayiwa J, Owor N, Namagambo B, Byaruhanga T, Wolf A, Lutwama JJ et al: Emergence, Epidemiology, and Transmission Dynamics of 2009 Pandemic A/ H1N1 Influenza in Kampala, Uganda, 2009-2015. The American Journal of Tropical Medicine and Hygiene 2017.

21. Barakat A, Benjouad A, Manuguerra JC, El Aouad $\mathrm{R}$, Van der Werf S: Virological surveillance in Africa can contribute to early detection of new genetic and antigenic lineages of influenza viruses. J Infect Dev Ctries 2011, 5(4):270-277.

22. Schoub BD: Surveillance and management of influenza on the African continent. Expert Rev Respir Med 2010, 4(2):167-169.

23. Thompson WW, Comanor L, Shay DK: Epidemiology of seasonal influenza: use of surveillance data and statistical models to estimate the burden of disease. The Journal of infectious diseases 2006, 194 Suppl 2:S82-91. 24. WHO: WHO Regional Offices. 2017. https://www. who.int/about/who-we-are/regional-offices (Assessed by 15 Mai 2019)

25. Ahmed MA, Awadalla NJ, Saleh AB: Clinical epidemiology comparison of H1N1 RT-PCR-positive and RT-PCR-negative pneumonia during the 2009-2010 pandemic in Mansoura University hospitals, Egypt. Influenza and other respiratory viruses 2011, 5(4):241-246.

26. Alonso WJ, Guillebaud J, Viboud C, Razanajatovo NH, Orelle A, Zhou SZ, Randrianasolo L, Heraud JM: Influenza seasonality in Madagascar: the mysterious African free-runner. Influenza and other respiratory viruses 2015, 9(3):101-109.

27. Ayele W, Demissie G, Kassa W, Zemelak E, Afework A, Amare B, Cox CM, Jima D: Challenges of establishing routine influenza sentinel surveillance in Ethiopia, 2008-2010. The Journal of Infectious Diseases2012, 206 Suppl 1:S41-45.

28. Budgell E, Cohen AL, McAnerney J, Walaza S, Madhi SA, Blumberg L, Dawood H, Kahn K, Tempia S, Venter $\mathrm{M}$ et al: Evaluation of two influenza surveillance systems in South Africa. PLoS One 2015, 10(3):e0120226. 29. Byarugaba DK, Erima B, Millard M, Kibuuka H, L L, Bwogi J, Mimbe D, Mworozi EA, Sharp B, Krauss S et al: Genetic analysis of influenza B viruses isolated in Uganda during the 2009-2010 seasons. Virology Journal 2013, 10:11.
30. Cardoso Y, Oliveira E, Vasconcelos J, Cohen AL, Francisco M: Characteristics of patients with influenza-like illness, severe acture respiratory illness, and laboratory-confirmed influenza at a major children's hospital in Angola, 2009-2011. The Journal of Infectious Diseases 2012, 206 Suppl 1:S136-139.

31. Cohen AL, Hellferscee O, Pretorius M, Treurnicht F, Walaza S, Madhi S, Groome M, Dawood H, Variava E, Kahn K et al: Epidemiology of influenza virus types and subtypes in South Africa, 2009-2012. Emerging Infectious Diseases 2014, 20(7):1162-1169.

32. Cummings MJ, Bakamutumaho B, Kayiwa J, Byaruhanga T, Owor N, Namagambo B, Wolf A, Wamala JF, Morse SS, Lutwama JJ et al: Epidemiologic and Spatiotemporal Characterization of Influenza and Severe Acute Respiratory Infection in Uganda, 2010-2015. Ann Am Thorac Soc 2016, 13(12):2159-2168.

33. Dalhatu IT, Medina-Marino A, Olsen SJ, Hwang I, Gubio AB, Ekanem EE, Coker EB, Akpan H, Adedeji AA: Influenza viruses in Nigeria, 2009-2010: results from the first 17 months of a national influenza sentinel surveillance system. The Journal of Infectious Diseases 2012, 206 Suppl 1:S121-128.

34. Maïnassara HB, Lagare A, Tempia S, Sidiki A, Issaka B, Abdou Sidikou B, O. OMO-B: Influenza Sentinel Surveillance among Patients with Influenza-Like-Illness and Severe Acute Respiratory Illness within the Framework of the National Reference Laboratory, Niger, 2009-2013. PLoS One 2015, 10(7):0133178.

35. Iyengar P, von Mollendorf C, Tempia S, Moerdyk A, Valley-Omar Z, Hellferscee O, Martinson N, Chhagan M, McMorrow M, Gambhir M et al: Case-ascertained study of household transmission of seasonal influenza - South Africa, 2013. J Infect 2015, 71(5):578-586.

36. Jones AH, Ampofo W, Akuffo R, Doman B, Duplessis C, Amankwa JA, Sarpong C, Sagoe K, Agbenohevi P, Puplampu $\mathrm{N}$ et al: Sentinel surveillance for influenza among severe acute respiratory infection and acute febrile illness inpatients at three hospitals in Ghana. Influenza and other respiratory viruses 2016, 10(5):367-374.

37. Jusot JF, Adamou L, Collard JM: Influenza transmission during a one-year period (2009-2010) in a Sahelian city: low temperature plays a major role. Influenza and other respiratory viruses 2012, 6(2):87-89.

38. Kadjo HA, Ekaza E, Coulibaly D, Kouassi DP, Nzussouo NT, Kouakou B, Ouattara A, Adjogoua EV, Akoua-Koffi CG, Elia GA et al: Sentinel surveillance for influenza and other respiratory viruses in Cote d'Ivoire, 2003-2010. Influenza Other Respir Viruses 2013, 7(3):296-303.

39. Katz MA, Muthoka P, Emukule GO, Kalani R, 
Njuguna H, Waiboci LW, Ahmed JA, Bigogo G, Feikin $\mathrm{DR}$, Njenga MK et al: Results from the first six years of national sentinel surveillance for influenza in Kenya, July 2007-June 2013. PLoS One 2014, 9(6):e98615.

40. Kebede S, Conteh IN, Steffen CA, Vandemaele K, Wurie I, Alemu W, Kuti-George F, Dafae F, Jambai A, Yahaya AA et al: Establishing a national influenza sentinel surveillance system in a limited resource setting, experience of Sierra Leone. Health Res Policy Syst 2013, 11:22.

41. Kronmann KC, Ampofo W, Nzussouo T, Wasfy MO, Agbenohevi P, Carroll J, Diabate M, Sourabie S, Puplampu N, Clemens $\mathrm{M}$ et al: Building military influenza surveillance capacity in West Africa. Military Medicine 2013, 178(3):306-314.

42. Lekana-Douki SE, Mouinga-Ondeme A, Nkoghe D, Drosten C, Drexler JF, Kazanji M, Leroy EM: Early introduction and delayed dissemination of pandemic influenza, Gabon. Emerging Infectious Diseases 2013, 19(4):644-647.

43. Majanja J, Njoroge RN, Achilla R, Wurapa EK, Wadegu M, Mukunzi S, Mwangi J, Njiri J, Gachara G, Bulimo W: Impact of influenza A(H1N1)pdm09 virus on circulation dynamics of seasonal influenza strains in Kenya. The American Journal of Tropical Medicine and Hygiene 2013, 88(5):940-945.

44. Makokha C, Mott J, Njuguna HN, Khagayi S, Verani JR, Nyawanda B, Otieno N, Katz MA: Comparison of severe acute respiratory illness (sari) and clinical pneumonia case definitions for the detection of influenza virus infections among hospitalized patients, western Kenya, 2009-2013. Influenza and other respiratory viruses 2016, 10(4):333-339.

45. Mmbaga VM, Mwasekaga MJ, Mmbuji P, Matonya M, Mwafulango A, Moshi S, Emukule G, Katz MA: Results from the first 30 months of national sentinel surveillance for influenza in Tanzania, 2008-2010. The Journal of Infectious Diseases 2012, 206 Suppl 1:S80-86.

46. Monamele GC, Vernet MA, Nsaibirni RFJ, Bigna JJR, Kenmoe S, Njankouo MR, Njouom R: Associations between meteorological parameters and influenza activity in a subtropical country: Case of five sentinel sites in Yaounde-Cameroon. PLoS One 2017, 12(10):e0186914. 47. Monamele GC, Vernet MA, Njankouo MR, Victoir K, Akoachere JF, Anong D, Njouom R: Genetic and antigenic characterization of influenza $\mathrm{A}(\mathrm{H} 3 \mathrm{~N} 2)$ in Cameroon during the 2014-2016 influenza seasons. PLoS One 2017, 12(9):e0184411.

48. El Moussi A, Ben Hadj Kacem MA, Ledesma J, Pozo F, Teresa Cuevas M, Casas I, Slim A: Genetic diversity of influenza B virus in 2009-2010 and 2010-
2011 in Tunisia. Med Mal Infect 2013, 43(8):337-344.

49. El Moussi A, Pozo F, Ben Hadj Kacem MA, Ledesma J, Cuevas MT, Casas I, Slim A: Virological Surveillance of Influenza Viruses during the 2008-09, 200910 and 2010-11 Seasons in Tunisia. PLoS One 2013, 8(9):e74064.

50. Ndegwa LK, Katz MA, McCormick K, Nganga Z, Mungai A, Emukule G, Kollmann MK, Mayieka L, Otieno J, Breiman RF et al: Surveillance for respiratory health care-associated infections among inpatients in 3 Kenyan hospitals, 2010-2012. Am J Infect Control 2014, 42(9):985-990.

51. N'Gattia A K, Coulibaly D, Nzussouo NT, Kadjo HA, Cherif D, Traore Y, Kouakou BK, Kouassi PD, Ekra KD, Dagnan NS et al: Effects of climatological parameters in modeling and forecasting seasonal influenza transmission in Abidjan, Cote d'Ivoire. BMC Public Health 2016, 16:972.

52. Onyango CO, Njeru R, Kazungu S, Achilla R, Bulimo W, Welch SR, Cane PA, Gunson RN, Hammitt LL, Scott JA et al: Influenza surveillance among children with pneumonia admitted to a district hospital in coastal Kenya, 2007-2010. The Journal of Infectious Diseases2012, 206 Suppl 1:S61-67.

53. Orelle A, Razanajatovo NH, Rajatonirina S, Hoffmann J, Randrianasolo L, Razafitrimo GM, Naidoo D, Richard V, Heraud JM: Epidemiological and virological characterization of 2009 pandemic influenza A virus subtype H1N1 in Madagascar. The Journal of Infectious Diseases 2012, 206 Suppl 1:S140-147.

54. Rajatonirina S, Heraud JM, Orelle A, Randrianasolo L, Razanajatovo N, Rajaona YR, Randrianarivo-Solofoniaina AE, Rakotomanana F, Richard V: The spread of influenza $\mathrm{A}(\mathrm{H} 1 \mathrm{~N} 1) \mathrm{pdm} 09$ virus in Madagascar described by a sentinel surveillance network. PLoS One 2012, 7(5):e37067.

55. Rakotoarisoa A, Randrianasolo L, Tempia S, Guillebaud J, Razanajatovo N, Randriamampionona L, Piola P, Halm A, Heraud JM: Evaluation of the influenza sentinel surveillance system in Madagascar, 2009-2014. Bulletin of the World Health Organization 2017, 95(5):375-381.

56. El Rhaffouli H, El Boukhrissi F, Bajjou T, Laraqui A, Hilali F, Bahji M, El Harrak M, Lahlou Amine I: Seroprevalence of pandemic influenza A (H1N1)pdm09 in two regions in Morocco following the 2010-2011 influenza season. Pathologie-Biologie 2013, 61(2):83-86.

57. El Rhaffouli H, El Fahime el M, Laraqui A, Bajjou T, Melloul M, Obeid S, Fathallah L, Lahlou-Amine I: Evolution of the hemagglutinin gene of the influenza $\mathrm{A}(\mathrm{H} 1 \mathrm{~N} 1) \mathrm{pdm} 09$ virus in Morocco during two influenza 
seasons 2009-2011. Curr Microbiol 2014, 68(3):372-380. 58. Seleka M, Treurnicht FK, Tempia S, Hellferscee O, Mtshali S, Cohen AL, Buys A, McAnerney JM, Besselaar TG, Pretorius $M$ et al: Epidemiology of influenza B/Yamagata and B/Victoria lineages in South Africa, 2005-2014. PLoS One 2017, 12(5):e0177655.

59. Venter M, Naidoo D, Pretorius M, Buys A, McAnerney J, Blumberg L, Madhi SA, Cohen C, Schoub B: Evolutionary dynamics of 2009 pandemic influenza A virus subtype H1N1 in South Africa during 2009-2010. The Journal of Infectious Diseases 2012, 206 Suppl 1:S166172.

60. Wabwire-Mangen F, Mimbe DE, Erima B, Mworozi EA, Millard M, Kibuuka H, Lukwago L, Bwogi J, Kiconco J, Tugume T et al: Epidemiology and Surveillance of Influenza Viruses in Uganda between 2008 and 2014. PLoS One 2016, 11(10):e0164861.

61. Waiboci LW, Mott JA, Kikwai G, Arunga G, Xu X, Mayieka L, Emukule GO, Muthoka P, Njenga MK, Fields BS et al: Which influenza vaccine formulation should be used in Kenya? A comparison of influenza isolates from Kenya to vaccine strains, 2007-2013. Vaccine 2016, 34(23):2593-2601.

62. Wane J, Nyatanyi T, Nkunda R, Rukelibuga J, Ahmed Z, Biedron C, Kabeja A, Muhimpundu MA, Kabanda A, Antara S et al: 2009 pandemic influenza A (H1N1) virus outbreak and response--Rwanda, October, 2009May, 2010. PLoS One 2012, 7(6):e31572.

63. Wong KK, Bulimo WD, Magana J, Achilla RA, Schwarcz SK, Simwa M, Majanja JM, Wadegu MO, Osuna FA, Mukunzi SO et al: Epidemiology of 2009 pandemic influenza A virus subtype H1N1 among Kenyans aged 2 months to 18 years, 2009-2010. The Journal of Infectious Diseases 2012, 206 Suppl 1:S68-73.

64. Refaey S, Amin M, Labib M, Kandeel A: Influenza virus positivity and circulating subtypes among cases of influenza-like illness and severe acute respiratory infection, Egypt, 2012-2015. East Mediterr Health J 2016, 22(7):527-536.

65. Elfalki F, Ihazmad H, Bimouhen A, Regragui Z, Benkaroum S, Bakri Y, Barakat A: Detection of influenza B viruses with reduced sensitivity to neuraminidase inhibitor in Morocco during 2014/15 season. East Mediterr Health J 2016, 22(7):453-459.

66. Mjid M, Cherif J, Toujani S, Mokkadem S, Saada I, Ben Salah N, Ouahchi Y, Louzir B, Mhiri N, Beji M: Infuenzae A (H1N1): about 189 cases. Tunis Med 2014, 92(12):748-751.

67. Tchidjou HK, Vescio F, Boros S, Guemkam G, Minka E, Lobe M, Cappelli G, Colizzi V, Tietche F, Rezza $\mathrm{G}$ : Seasonal pattern of hospitalization from acute res- piratory infections in Yaounde, Cameroon. Journal of Tropical Pediatrics 2010, 56(5):317-320.

68. Ait-Aissa A, Derrar F, Hannoun D, Gradi EA, Scaravelli D, Bouslama Z: Surveillance for antiviral resistance among influenza viruses circulating in Algeria during five consecutive influenza seasons (2009-2014). Journal of Medical Virology 2018, 90(5):844-853.

69. Ho A, Mallewa J, Peterson I, SanJoaquin M, Garg S, Bar-Zeev N, Menyere M, Alaerts M, Mapurisa G, Chilombe $\mathrm{M}$ et al: Epidemiology of Severe Acute Respiratory Illness and Risk Factors for Influenza Infection and Clinical Severity among Adults in Malawi, 20112013. The American Journal of Tropical Medicine and Hygiene 2018, 99(3):772-779.

70. Kavunga-Membo H, Nkwembe E, Simulundu E, Karhemere S, Babakazo P, Manya L, Kabamba J, Okitolonda E, Ahuka-Mundeke S, Muyembe JJ: Epidemiology of circulating human influenza viruses from the Democratic Republic of Congo, 2015. PLoS One 2018, 13(9):e0203995.

71. Monamele CG, Vernet MA, Njankouo MR, Kenmoe S, Schoenhals M, Yahaya AA, Anong DN, Akoachere JF, Njouom R: Genetic characterization of influenza B virus in Cameroon and high frequency of reassortant strains. Journal of Medical Virology 2018, 90(12):18481855.

72. Nguenha N, Tivane A, Pale M, Machalele L, Nacoto A, Pires G, Mationane E, Salencia J, Gundane F, Muteto $D$ et al: Clinical and epidemiological characterization of influenza virus infections in children with severe acute respiratory infection in Maputo, Mozambique: Results from the implementation of sentinel surveillance, 2014 - 2016. PLoS One 2018, 13(3):e0194138.

73. Sagna T, Ilboudo AK, Wandaogo C, Cisse A, Sana M, Tialla D, Sanou AM, Muscatello DJ, Tarnagda Z: Preliminary results of official influenza and acute respiratory infection surveillance in two towns of Burkina Faso, 2013-2015. BMC Infectious Diseases 2018, 18(1):330. 74. Sanou AM, Wandaogo SCM, Poda A, Tamini L, Kyere AE, Sagna T, Ouedraogo MS, Pauly M, Hubschen JM, Muller CP et al: Epidemiology and molecular characterization of influenza viruses in Burkina Faso, sub-Saharan Africa. Influenza and other respiratory viruses 2018, 12(4):490-496.

75. Tivane A, Daniels R, Nguenha N, Machalele L, Nacoto A, Pale M, Mateonane E, Mavale S, Chilundo J, Muteto D et al: Antigenic and genetic characterization of influenza viruses isolated in Mozambique during the 2015 season. PLoS One 2018, 13(7):e0201248.

76. Valley-Omar Z, Iyengar P, von Mollendorf C, Tempia S, Moerdyk A, Hellferscee O, Martinson N, Mc- 
Morrow M, Variava E, Masonoke $\mathrm{K}$ et al: Intra-host and intra-household diversity of influenza $A$ viruses during household transmissions in the 2013 season in 2 peri-urban communities of South Africa. PLoS One 2018, 13(5):e0198101.

77. Woyessa AB, Mengesha M, Belay D, Tayachew A, Ayele W, Beyene B, Kassa W, Zemelak E, Demissie G, Amare $B$ et al: Epidemiology of influenza in Ethiopia: findings from influenza sentinel surveillance and respiratory infection outbreak investigations, 2009-2015. BMC Infectious Diseases 2018, 18(1):449.

78. Yang W, Cummings MJ, Bakamutumaho B, Kayiwa J, Owor N, Namagambo B, Byaruhanga T, Lutwama JJ, O'Donnell MR, Shaman J: Dynamics of influenza in tropical Africa: Temperature, humidity, and co-circulating (sub)types. Influenza and other respiratory viruses 2018, 12(4):446-456.

79. Yang W, Cummings MJ, Bakamutumaho B, Kayiwa J, Owor N, Namagambo B, Byaruhanga T, Lutwama JJ, O'Donnell MR, Shaman J: Transmission dynamics of influenza in two major cities of Uganda. Epidemics 2018, 24:43-48.

80. Andayi F, Chaves SS, Widdowson MA: Impact of the 1918 Influenza Pandemic in Coastal Kenya. Trop Med Infect Dis 2019, 4(2).

81. Babakazo P, Kabamba-Tshilobo J, Wemakoy EO, Lubula L, Manya LK, Ilunga BK, Disasuani W, Nkwembe E, Kavunga-Membo H, Changachanga JC et al: Evaluation of the influenza sentinel surveillance system in the Democratic Republic of Congo, 2012-2015. BMC Public Health 2019, 19(1):1652.

82. Emukule GO, Otiato F, Nyawanda BO, Otieno NA, Ochieng CA, Ndegwa LK, Muturi P, Bigogo G, Verani JR, Muthoka PM et al: The Epidemiology and Burden of Influenza B/Victoria and B/Yamagata Lineages in Kenya, 2012-2016. Open Forum Infect Dis 2019, 6(10):ofz421.

83. Kleynhans J, Treurnicht FK, Cohen C, Vedan T, Seleka M, Maki L, von Gottberg A, McCarthy K, Ramkrishna W, McMorrow M et al: Outbreak of influenza A in a boarding school in South Africa, 2016. Pan Afr Med J 2019, 33:42.

84. Monamele CG, Munshili Njifon HL, Vernet MA, Njankouo MR, Kenmoe S, Yahaya AA, Deweerdt L, Nono R, Mbacham W, Anong DN et al: Molecular characterization of influenza A(H1N1)pdm09 in Cameroon during the 2014-2016 influenza seasons. PLoS One 2019, 14(1):e210119.

85. Ngobeni H, Tempia S, Cohen AL, Walaza S, Kuonza L, Musekiwa A, von Gottberg A, Hellferscee O, Wolter N, Treurnicht FK et al: The performance of dif- ferent case definitions for severe influenza surveillance among HIV-infected and HIV-uninfected children aged $<5$ years in South Africa, 2011-2015. PLoS One 2019, 14(9):e0222294.

86. Njouom R, Monamele GC, Ermetal B, Tchatchouang S, Moyo-Tetang S, McCauley JW, Daniels RS: Detection of Influenza C Virus Infection among Hospitalized Patients, Cameroon. Emerging Infectious Diseases 2019, 25(3):607-609.

87. Nuvey FS, Edu-Quansah EP, Kuma GK, Eleeza J, Kenu E, Sackey S, Ameme D, Abakar MF, Kreppel K, Ngandolo RB et al: Evaluation of the sentinel surveillance system for influenza-like illnesses in the Greater Accra region, Ghana, 2018. PLoS One 2019, 14(3):e0213627.

88. Treurnicht FK, Buys A, Tempia S, Seleka M, Cohen AL, Walaza S, Glass AJ, Rossouw I, McAnerney J, Blumberg L et al: Replacement of neuraminidase inhibitor-susceptible influenza $\mathrm{A}(\mathrm{H} 1 \mathrm{~N} 1)$ with resistant phenotype in 2008 and circulation of susceptible influenza A and B viruses during 2009-2013, South Africa. Influenza and other respiratory viruses 2019, 13(1):54-63.

89. Yazidi R, Aissi W, Bouguerra H, Nouira M, Kharroubi G, Maazaoui L, Zorraga M, Abdeddaiem N, Chlif S, El Moussi A et al: Evaluation of the influenza-like illness surveillance system in Tunisia, 2012-2015. BMC Public Health 2019, 19(1):694.

90. Munshili Njifon HL, Monamele CG, Kengne Nde C, Vernet MA, Bouba G, Tchatchouang S, Njankouo MR, Tapondjou R, Deweerdt L, Mbacham W et al: Influence of meteorological parameters in the seasonality of influenza viruses circulating in Northern Cameroon. Influenza and other respiratory viruses 2019, 13(2):158-165.

91. Soli R, Kaabi B, Barhoumi M, Maktouf C, Ahmed SB: Bayesian phylogenetic analysis of the influenza-A virus genomes isolated in Tunisia, and determination of potential recombination events. Mol Phylogenet Evol 2019, 134:253-268.

92. Dia N, Ndiaye MN, Monteiro Mde L, Koivogui L, Bara MO, Diop OM: A subregional analysis of epidemiologic and genetic characteristics of influenza A(H1N1)pdm09 in Africa: Senegal, Cape Verde, Mauritania, and Guinea, 2009-2010. The American Journal of Tropical Medicine and Hygiene 2013, 88(5):946-953.

93. Nelson MI, Njouom R, Viboud C, Niang MN, Kadjo H, Ampofo W, Adebayo A, Tarnagda Z, Miller MA, Holmes EC et al: Multiyear persistence of 2 pandemic A/H1N1 influenza virus lineages in West Africa. The Journal of Infectious Diseases 2014, 210(1):121-125.

94. Nzussouo NT, Michalove J, Diop OM, Njouom R, Monteiro Mde L, Adje HK, Manoncourt S, Amankwa 
J, Koivogui L, Sow S et al: Delayed 2009 pandemic influenza A virus subtype H1N1 circulation in West Africa, May 2009-April 2010. The Journal of Infectious Diseases 2012, 206 Suppl 1:S101-107.

95. Abadom TR, Smith AD, Tempia S, Madhi SA, Cohen C, Cohen AL: Risk factors associated with hospitalisation for influenza-associated severe acute respiratory illness in South Africa: A case-population study. Vaccine 2016, 34(46):5649-5655.

96. Barakat A, Ihazmad H, El Falaki F, Tempia S, Cherkaoui I, El Aouad R: 2009 Pandemic influenza A virus subtype H1N1 in Morocco, 2009-2010: epidemiology, transmissibility, and factors associated with fatal cases. The Journal of Infectious Diseases 2012, 206 Suppl 1:S94100.

97. El Kholy AA, Mostafa NA, Ali AA, El-Sherbini SA, Ismail RI, Magdy RI, Soliman MS, Said MM: Risk factors of prolonged hospital stay in children with viral severe acute respiratory infections. J Infect Dev Ctries 2014, 8(10):1285-1293.

98. Tempia S, Walaza S, Moyes J, Cohen AL, von Mollendorf C, Treurnicht FK, Venter M, Pretorius M, Hellferscee O, Mtshali S et al: Risk Factors for Influenza-Associated Severe Acute Respiratory Illness Hospitalization in South Africa, 2012-2015. Open Forum Infect Dis 2017, 4(1):ofw262.

99. Bouneb R, Mellouli M, Bensoltane H, Baroudi J, Chouchene I, Boussarsar M: Characteristics and outcome of ill critical patients with influenza $\mathrm{A}$ infection. Pan Afr Med J 2018, 29:174.

100. Cohen C, Moyes J, Tempia S, Groom M, Walaza S, Pretorius M, Dawood H, Chhagan M, Haffejee S, Variava $\mathrm{E}$ et al: Severe influenza-associated respiratory infection in high HIV prevalence setting, South Africa, 2009-2011. Emerging Infectious Diseases 2013, 19(11):17661774.

101. Dangor Z, Izu A, Moore DP, Nunes MC, Solomon F, Beylis N, von Gottberg A, McAnerney JM, Madhi SA: Temporal association in hospitalizations for tuberculosis, invasive pneumococcal disease and influenza virus illness in South African children. PLoS One 2014, 9(3):e91464.

102. Ho A, Aston SJ, Jary H, Mitchell T, Alaerts M, Menyere M, Mallewa J, Nyirenda M, Everett D, Heyderman RS et al: Impact of HIV on the burden and severity of influenza illness in Malawian adults: a prospective cohort and parallel case-control study. Clinical infectious diseases: an official publication of the Infectious Diseases Society of America 2017.

103. Peterson I, Bar-Zeev N, Kennedy N, Ho A, Newberry L, SanJoaquin MA, Menyere M, Alaerts M, Mapurisa $G$, Chilombe $M$ et al: Respiratory Virus-Associated
Severe Acute Respiratory Illness and Viral Clustering in Malawian Children in a Setting With a High Prevalence of HIV Infection, Malaria, and Malnutrition. The Journal of Infectious Diseases 2016, 214(11):1700-1711.

104. Thompson MG, Breiman RF, Hamel MJ, Desai M, Emukule G, Khagayi S, Shay DK, Morales K, Kariuki S, Bigogo GM et al: Influenza and malaria coinfection among young children in western Kenya, 2009-2011. The Journal of Infectious Diseases 2012, 206(11):1674-1684. 105. von Mollendorf C, Hellferscee O, Valley-Omar Z, Treurnicht FK, Walaza S, Martinson NA, Lebina L, Mothlaoleng K, Mahlase G, Variava E et al: Influenza Viral Shedding in a Prospective Cohort of HIV-Infected and Uninfected Children and Adults in 2 Provinces of South Africa, 2012-2014. The Journal of Infectious Diseases 2018, 218(8):1228-1237.

106. Walaza S, Cohen C, Nanoo A, Cohen AL, McAnerney J, von Mollendorf C, Moyes J, Tempia S: Excess Mortality Associated with Influenza among Tuberculosis Deaths in South Africa, 1999-2009. PLoS One 2015, 10(6):e0129173.

107. Wolter N, Cohen C, Tempia S, Madhi SA, Venter M, Moyes J, Walaza S, Malope Kgokong B, Groome M, $\mathrm{du}$ Plessis $\mathrm{M}$ et al: HIV and influenza virus infections are associated with increased blood pneumococcal load: a prospective, hospital-based observational study in South Africa, 2009-2011. J Infect Dis 2014, 209(1):56-65. 108. Cohen C, Tshangela A, Valley-Omar Z, Iyengar P, Von Mollendorf C, Walaza S, Hellferscee O, Venter M, Martinson N, Mahlase G et al: Household Transmission of Seasonal Influenza From HIV-Infected and HIV-Uninfected Individuals in South Africa, 2013-2014. The Journal of Infectious Diseases 2019, 219(10):1605-1615. 109. Walaza S, Tempia S, Dawood H, Variava E, Wolter N, Dreyer A, Moyes J, Von Mollendorf C, McMorrow M, Von Gottberg A et al: The Impact of Influenza and Tuberculosis Interaction on Mortality Among Individuals Aged $>/=15$ Years Hospitalized With Severe Respiratory Illness in South Africa, 2010-2016. Open Forum Infect Dis 2019, 6(3):ofz020.

110. Cohen C, Walaza S, Treurnicht FK, McMorrow M, Madhi SA, McAnerney JM, Tempia S: In- and Out-of-hospital Mortality Associated with Seasonal and Pandemic Influenza and Respiratory Syncytial Virus in South Africa, 2009-2013. Clinical infectious diseases : an official publication of the Infectious Diseases Society of America 2017.

111. Cohen C, Moyes J, Tempia S, Groome M, Walaza S, Pretorius M, Dawood H, Chhagan M, Haffejee S, Variava E et al: Mortality amongst patients with influenza-associated severe acute respiratory illness, South Africa, 2009-2013. PLoS One 2015, 10(3):e0118884. 
112. Damak H, Chtara K, Bahloul M, Kallel H, Chaari A, Ksibi H, Chelly H, Rekik N, Ben Hamida C, Bouaziz $\mathrm{M}$ : Clinical features, complications and mortality in critically ill patients with 2009 influenza A(H1N1) in Sfax,Tunisia. Influenza and other respiratory viruses 2011, 5(4):230-240.

113. Dawa JA, Chaves SS, Nyawanda B, Njuguna HN, Makokha C, Otieno NA, Anzala O, Widdowson MA, Emukule GO: National burden of hospitalized and non-hospitalized influenza-associated severe acute respiratory illness in Kenya, 2012-2014. Influenza and other respiratory viruses 2017.

114. Divala TH, Kalilani-Phiri L, Mawindo P, Nyirenda O, Kapito-Tembo A, Laufer MK: Incidence and Seasonality of Influenza-Like Illnesses Among Pregnant Women in Blantyre, Malawi. The American Journal of Tropical Medicine and Hygiene 2016, 95(4):915-917.

115. Diene Sarr F, Niang M, Thiam D, Dia N, Badiane A, Ndao AB, Sokhna C, Spiegel A, Richard V: Acute Febrile Illness and Influenza Disease Burden in a Rural Cohort Dedicated to Malaria in Senegal, 2012-2013. PLoS One 2015, 10(12):e0143999.

116. Emukule GO, Spreeuwenberg P, Chaves SS, Mott JA, Tempia S, Bigogo G, Nyawanda B, Nyaguara A, Widdowson MA, van der Velden $\mathrm{K}$ et al: Estimating influenza and respiratory syncytial virus-associated mortality in Western Kenya using health and demographic surveillance system data, 2007-2013. PLoS One 2017, 12(7):e0180890.

117. Gabor JJ, Schwarz NG, Esen M, Kremsner PG, Grobusch MP: Influenza A and Parvovirus B19 Seropositivity Rates in Gabonese Infants. The American Journal of Tropical Medicine and Hygiene 2015, 93(2):407-409.

118. Gul D, Cohen C, Tempia S, Newall AT, Muscatello DJ: Influenza-associated mortality in South Africa, 2009-2013: The importance of choices related to influenza infection proxies. Influenza and other respiratory viruses 2017.

119. Hogan B, Ammer L, Zimmermann M, Binger T, Krumkamp R, Sarpong N, Rettig T, Dekker D, Kreuels B, Reigl L et al: Burden of influenza among hospitalized febrile children in Ghana. Influenza and other respiratory viruses 2017.

120. Kandeel A, Dawson P, Labib M, Said M, El-Refai S, El-Gohari A, Talaat M: Morbidity, Mortality, and Seasonality of Influenza Hospitalizations in Egypt, November 2007-November 2014. PLoS One 2016, 11(9):e0161301.

121. Khattab A, Shaheen M, Kamel T, El Faramay A, El Rahman SA, Nabil D, Gouda M: Burden of pediatric influenza $A$ virus infection post swine-flu H1N1 pandemic in Egypt. Asian Pac J Trop Med 2013, 6(9):693698.

122. Kyeyagalire R, Tempia S, Cohen AL, Smith AD, McAnerney JM, Dermaux-Msimang V, Cohen C: Hospitalizations associated with influenza and respiratory syncytial virus among patients attending a network of private hospitals in South Africa, 2007-2012. BMC Infectious Diseases 2014, 14:694.

123. McMorrow ML, Emukule GO, Njuguna HN, Bigogo G, Montgomery JM, Nyawanda B, Audi A, Breiman RF, Katz MA, Cosmas L et al: The Unrecognized Burden of Influenza in Young Kenyan Children, 20082012. PLoS One 2015, 10(9):e0138272.

124. Mohamed GA, Ahmed JA, Marano N, Mohamed A, Moturi E, Burton W, Otieno S, Fields B, Montgomery J, Kabugi W et al: Etiology and Incidence of Viral Acute Respiratory Infections Among Refugees Aged 5 Years and Older in Hagadera Camp, Dadaab, Kenya. The American Journal of Tropical Medicine and Hygiene 2015, 93(6):1371-1376.

125. Murray J, Cohen A, Walaza S, Groome M, Madhi S, Variava E, Kahn K, Dawood H, Tempia S, Tshangela A et al: Determining the Provincial and National Burden of Influenza-Associated Severe Acute Respiratory Illness in South Africa Using a Rapid Assessment Methodology. PLoS One 2015, 10(7):e0132078.

126. Ntiri MP, Duque J, McMorrow ML, Frimpong JA, Parbie P, Badji E, Nzussouo NT, Benson EM, Adjabeng M, Dueger E et al: Incidence of medically attended influenza among residents of Shai-Osudoku and Ningo-Prampram Districts, Ghana, May 2013 - April 2015. BMC Infectious Diseases 2016, 16(1):757.

127. Nyamusore J, Rukelibuga J, Mutagoma M, Muhire A, Kabanda A, Williams T, Mutoni A, Kamwesiga J, Nyatanyi T, Omolo J et al: The national burden of influenza-associated severe acute respiratory illness hospitalization in Rwanda, 2012-2014. Influenza and other respiratory viruses 2017.

128. Rowlinson E, Dueger E, Mansour A, Azzazy N, Mansour H, Peters L, Rosenstock S, Hamid S, Said MM, Geneidy $\mathrm{M}$ et al: Incidence and etiology of hospitalized acute respiratory infections in the Egyptian Delta. Influenza and other respiratory viruses 2017, 11(1):23-32.

129. Tempia S, Walaza S, Moyes J, Cohen AL, von Mollendorf C, McMorrow ML, Mhlanga S, Treurnicht FK, Venter M, Pretorius $M$ et al: The Effects of the Attributable Fraction and the Duration of Symptoms on Burden Estimates of Influenza-Associated Respiratory Illnesses in a High HIV-Prevalence Setting, South Africa, 2013-2015. Influenza and other respiratory viruses 2017. 130. Theo A, Tempia S, Cohen AL, Simusika P, Chentu- 
lo E, Chikamukwa CM, Monze M: The national burden of influenza-associated severe acute respiratory illness hospitalization in Zambia, 2011-2014. Influenza and other respiratory viruses 2017.

131. Chlif S, Aissi W, Bettaieb J, Kharroubi G, Nouira M, Yazidi R, El Moussi A, Maazaoui L, Slim A, Salah AB: Modelling of seasonal influenza and estimation of the burden in Tunisia. East Mediterr Health J 2016, 22(7):460-467.

132. Refaey S, Hassan M, Mansour A, Kandeel A: Incidence of influenza virus-associated severe acute respiratory infection in Damanhour district, Egypt, 2013. East Mediterr Health J 2016, 22(7):503-512.

133. Cohen C, Walaza S, Moyes J, Groome M, Tempia S, Pretorius M, Hellferscee O, Dawood H, Chhagan M, Naby F et al: Epidemiology of viral-associated acute lower respiratory tract infection among children $<5$ years of age in a high HIV prevalence setting, South Africa, 2009-2012. The Pediatric Infectious Disease Journal 2015, 34(1):66-72.

134. Tempia S, Walaza S, Moyes J, Cohen AL, von Mollendorf C, McMorrow ML, Treurnicht FK, Venter M, Pretorius M, Hellferscee $\mathrm{O}$ et al: Attributable Fraction of Influenza Virus Detection to Mild and Severe Respiratory Illnesses in HIV-Infected and HIV-Uninfected Patients, South Africa, 2012-2016. Emerging Infectious Diseases 2017, 23(7):1124-1132.

135. Babakazo P, Lubula L, Disasuani W, Manya LK, Nkwembe E, Mitongo N, Kavunga-Membo H, Changachanga JC, Muhemedi S, Ilunga BK et al: The national and provincial burden of medically attended influenza-associated influenza-like illness and severe acute respiratory illness in the Democratic Republic of Congo, 2013-2015. Influenza and other respiratory viruses 2018, 12(6):695-705.

136. Tempia S, Walaza S, Moyes J, Cohen AL, McMorrow ML, Treurnicht FK, Hellferscee O, Wolter N, von Gottberg A, Nguweneza A et al: Quantifying How Different Clinical Presentations, Levels of Severity, and Healthcare Attendance Shape the Burden of Influenza-associated Illness: A Modeling Study From South Africa. Clinical Infectious Diseases 2018.

137. Rabarison JH, Tempia S, Harimanana A, Guillebaud J, Razanajatovo NH, Ratsitorahina M, Heraud JM: Burden and Epidemiology of Influenza- and Respiratory Syncytial Virus-Associated Severe Acute Respiratory Illness Hospitalization in Madagascar, 2011-2016. Influenza and other respiratory viruses 2018.

138. Emukule GO, Namagambo B, Owor N, Bakamutumaho B, Kayiwa JT, Namulondo J, Byaruhanga T, Tempia S, Chaves SS, Lutwama JJ: Influenza-associat- ed pneumonia hospitalizations in Uganda, 2013-2016. PLoS One 2019, 14(7):e0219012.

139. McMorrow ML, Tempia S, Walaza S, Treurnicht FK, Moyes J, Cohen AL, Pretorius M, Hellferscee O, Wolter N, von Gottberg A et al: The Role of Human Immunodeficiency Virus in Influenza- and Respiratory Syncytial Virus-associated Hospitalizations in South African Children, 2011-2016. Clinical infectious diseases: an official publication of the Infectious Diseases Society of America 2019, 68(5):773-780.

140. McMorrow ML, Tempia S, Walaza S, Treurnicht FK, Ramkrishna W, Azziz-Baumgartner E, Madhi SA, Cohen C: Prioritization of risk groups for influenza vaccination in resource limited settings - A case study from South Africa. Vaccine 2019, 37(1):25-33.

141. Rabarison JH, Tempia S, Harimanana A, Guillebaud J, Razanajatovo NH, Ratsitorahina M, Heraud JM: Burden and epidemiology of influenza- and respiratory syncytial virus-associated severe acute respiratory illness hospitalization in Madagascar, 2011-2016. Influenza and other respiratory viruses 2019, 13(2):138-147.

142. Tempia S, Moyes J, Cohen AL, Walaza S, Edoka I, McMorrow ML, Treurnicht FK, Hellferscee O, Wolter $\mathrm{N}$, von Gottberg A et al: Health and economic burden of influenza-associated illness in South Africa, 20132015. Influenza and other respiratory viruses 2019, 13(5):484495.

143. Tempia S, Walaza S, Moyes J, Cohen AL, McMorrow ML, Treurnicht FK, Hellferscee O, Wolter N, von Gottberg A, Nguweneza A et al: Quantifying How Different Clinical Presentations, Levels of Severity, and Healthcare Attendance Shape the Burden of Influenza-associated Illness: A Modeling Study From South Africa. Clinical infectious diseases: an official publication of the Infectious Diseases Society of America 2019, 69(6):10361048.

144. McMorrow ML, Wemakoy EO, Tshilobo JK, Emukule GO, Mott JA, Njuguna H, Waiboci L, Heraud JM, Rajatonirina S, Razanajatovo NH et al: Severe Acute Respiratory Illness Deaths in Sub-Saharan Africa and the Role of Influenza: A Case Series From 8 Countries. The Journal of Infectious Diseases 2015, 212(6):853860.

145. Benet T, Sylla M, Messaoudi M, Sanchez Picot V, Telles JN, Diakite AA, Komurian-Pradel F, Endtz H, Diallo S, Paranhos-Baccala G et al: Etiology and Factors Associated with Pneumonia in Children under 5 Years of Age in Mali: A Prospective Case-Control Study. PLoS One 2015, 10(12):e0145447.

146. Breiman RF, Cosmas L, Njenga M, Williamson J, Mott JA, Katz MA, Erdman DD, Schneider E, Oberste 
M, Neatherlin JC et al: Severe acute respiratory infection in children in a densely populated urban slum in Kenya, 2007-2011. BMC Infectious Diseases 2015, 15:95. 147. Dia N, Richard V, Kiori D, Cisse el HA, Sarr FD, Faye A, Goudiaby DG, Diop OM, Niang MN: Respiratory viruses associated with patients older than 50 years presenting with ILI in Senegal, 2009 to 2011. BMC Infectious Diseases 2014, 14:189.

148. Enan KA, Nabeshima T, Kubo T, Buerano CC, El Hussein AR, Elkhidir IM, Khalil EA, Morita K: Survey of causative agents for acute respiratory infections among patients in Khartoum-State, Sudan, 2010-2011. Virology Journal 2013, 10:312.

149. Feikin DR, Njenga MK, Bigogo G, Aura B, Aol G, Audi A, Jagero G, Muluare PO, Gikunju S, Nderitu L et al: Viral and bacterial causes of severe acute respiratory illness among children aged less than 5 years in a high malaria prevalence area of western Kenya, 2007-2010. Pediatr Infect Dis J 2013, 32(1):e14-19.

150. Grassi T, Mancini F, Ciervo A, Vescio MF, Ghazal A, Ashour H, Saleh E, El Zalabani M, Donatelli I, El Sawaf G et al: Chlamydophila pneumoniae, Mycoplasma pneumoniae, and influenza in children with respiratory infections in Alexandria, Egypt. J Infect Dev Ctries 2014, 8(3):379-383.

151. Hoffmann J, Rabezanahary $\mathrm{H}$, Randriamarotia $\mathrm{M}$, Ratsimbasoa A, Najjar J, Vernet G, Contamin B, Paranhos-Baccala G: Viral and atypical bacterial etiology of acute respiratory infections in children under 5 years old living in a rural tropical area of Madagascar. PLoS One 2012, 7(8):e43666.

152. Kenmoe S, Tchendjou P, Vernet MA, Moyo-Tetang S, Mossus T, Njankouo-Ripa M, Kenne A, Penlap Beng V, Vabret A, Njouom R: Viral etiology of severe acute respiratory infections in hospitalized children in Cameroon, 2011-2013. Influenza and other respiratory viruses 2016, 10(5):386-393.

153. Kwofie TB, Anane YA, Nkrumah B, Annan A, Nguah SB, Owusu M: Respiratory viruses in children hospitalized for acute lower respiratory tract infection in Ghana. Virology Journal 2012, 9:78.

154. Lekana-Douki SE, Nkoghe D, Drosten C, Ngoungou EB, Drexler JF, Leroy EM: Viral etiology and seasonality of influenza-like illness in Gabon, March 2010 to June 2011. BMC Infectious Diseases 2014, 14:373.

155. Ouedraogo S, Traore B, Nene Bi ZA, Yonli FT, Kima D, Bonane P, Congo L, Traore RO, Ye D, Marguet $\mathrm{C}$ et al: Viral etiology of respiratory tract infections in children at the pediatric hospital in ouagadougou (burkina faso). PLoS One 2014, 9(10):e110435.

156. Pale M, Nacoto A, Tivane A, Nguenha N, Machalele L, Gundane F, Muteto D, Chilundo J, Mavale S, Se-
ma-Baltazar C et al: Respiratory syncytial and influenza viruses in children under 2 years old with severe acute respiratory infection (SARI) in Maputo, 2015. PLoS One 2017, 12(11):e0186735.

157. Pretorius MA, Madhi SA, Cohen C, Naidoo D, Groome M, Moyes J, Buys A, Walaza S, Dawood H, Chhagan $\mathrm{M}$ et al: Respiratory viral coinfections identified by a 10-plex real-time reverse-transcription polymerase chain reaction assay in patients hospitalized with severe acute respiratory illness--South Africa, 2009-2010. J Infect Dis 2012, 206 Suppl 1:S159-165.

158. Pretorius MA, Tempia S, Walaza S, Cohen AL, Moyes J, Variava E, Dawood H, Seleka M, Hellferscee O, Treurnicht $F$ et al: The role of influenza, RSV and other common respiratory viruses in severe acute respiratory infections and influenza-like illness in a population with a high HIV sero-prevalence, South Africa 2012-2015. Journal of clinical virology: the official publication of the Pan American Society for Clinical Virology 2016, 75:21-26.

159. Wolter N, Tempia S, Cohen C, Madhi SA, Venter M, Moyes J, Walaza S, Malope-Kgokong B, Groome M, du Plessis $\mathrm{M}$ et al: High nasopharyngeal pneumococcal density, increased by viral coinfection, is associated with invasive pneumococcal pneumonia. The Journal of Infectious Diseases 2014, 210(10):1649-1657.

160. Zar HJ, Barnett W, Stadler A, Gardner-Lubbe S, Myer L, Nicol MP: Aetiology of childhood pneumonia in a well vaccinated South African birth cohort: a nested case-control study of the Drakenstein Child Health Study. The Lancet Respiratory Medicine 2016, 4(6):463-472. 161. Tantawy AA, Barakat MM, Adly AA, Ebeid FS, Shamaa MF, Yassin M: One-Year Prospective Study of Community Acquired Influenza and Parainfluenza Viral Infections in Hospitalized Egyptian Children with Malignancy: Single Center Experience. Pediatr Hematol Oncol 2015, 32(5):304-314.

162. Famoroti T, Sibanda W, Ndung'u T: Prevalence and seasonality of common viral respiratory pathogens, including Cytomegalovirus in children, between 0-5 years of age in KwaZulu-Natal, an HIV endemic province in South Africa. BMC Pediatr 2018, 18(1):240.

163. Tine RC, Ndiaye LA, Niang MN, Kiori DE, Dia $\mathrm{N}$, Gaye $\mathrm{O}$, Broutin $\mathrm{H}$ : Upper respiratory infections in a rural area with reduced malaria transmission in Senegal: a pathogens community study. BMC Infectious Diseases 2018, 18(1):459.

164. Dia N, Diene Sarr F, Thiam D, Faye Sarr T, Espie E, OmarBa I, Coly M, Niang M, Richard V: Influenza-like illnesses in Senegal: not only focus on influenza viruses. PLoS One 2014, 9(3):e93227.

165. Razanajatovo NH, Guillebaud J, Harimanana A, Rajatonirina S, Ratsima EH, Andrianirina ZZ, 
Rakotoariniaina H, Andriatahina T, Orelle A, Ratovoson $\mathrm{R}$ et al: Epidemiology of severe acute respiratory infections from hospital-based surveillance in Madagascar, November 2010 to July 2013. PLoS One 2018, 13(11):e0205124.

166. Lagare A, Ousmane S, Dano ID, Issaka B, Issa I, Mainassara HB, Testa J, Tempia S, Mamadou S: Molecular detection of respiratory pathogens among children aged younger than 5 years hospitalized with febrile acute respiratory infections: A prospective hospital-based observational study in Niamey, Niger. Health Sci Rep 2019, 2(11):e137.

167. Mackenzie GA, Vilane A, Salaudeen R, Hogerwerf L, van den Brink S, Wijsman LA, Overduin P, Janssens TKS, de Silva TI, van der Sande MAB et al: Respiratory syncytial, parainfluenza and influenza virus infection in young children with acute lower respiratory infection in rural Gambia. Sci Rep 2019, 9(1):17965.

168. Chaabane A, Aouam K, Ben Fredj N, Toumi A, Braham D, N AB, Chakroun M: H1N1 influenza vaccines in Tunisia: efficiency and safety. Therapie 2011, 66(3):281-289.

169. Dangor Z, Nunes MC, Kwatra G, Lala SG, Madhi SA: Vaccination of HIV-infected pregnant women: implications for protection of their young infants. Trop Dis Travel Med Vaccines 2017, 3:1.

170. Dembinski JL, Mihret A, Yimer SA, Tessema B, Trieu MC, Tarekegn A, Getachew N, Cox RJ, Oftung F, Haneberg B et al: High Prevalence of Humoral and Cellular Immunity to Influenza Viruses in Preschool Children Living in Addis Ababa, Ethiopia. Open Forum Infect Dis 2017, 4(1):ofx026.

171. Katz MA, Lebo E, Emukule GO, Otieno N, Caselton DL, Bigogo G, Njuguna H, Muthoka PM, Waiboci LW, Widdowson MA et al: Uptake and Effectiveness of a Trivalent Inactivated Influenza Vaccine in Children in Urban and Rural Kenya, 2010 to 2012. The Pediatric Infectious Disease Journal 2016, 35(3):322-329.

172. Madhi SA, Cutland CL, Kuwanda L, Weinberg A, Hugo A, Jones S, Adrian PV, van Niekerk N, Treurnicht F, Ortiz JR et al: Influenza vaccination of pregnant women and protection of their infants. $N$ Engl J Med 2014, 371(10):918-931.

173. Madhi SA, Dittmer S, Kuwanda L, Venter M, Cassim H, Lazarus E, Thomas T, Liberty A, Treurnich F, Cutland CL et al: Efficacy and immunogenicity of influenza vaccine in HIV-infected children: a randomized, double-blind, placebo controlled trial. AIDS 2013, 27(3):369-379.

174. Madhi SA, Maskew M, Koen A, Kuwanda L, Besselaar TG, Naidoo D, Cohen C, Valette M, Cutland CL,
Sanne I: Trivalent inactivated influenza vaccine in African adults infected with human immunodeficient virus: double blind, randomized clinical trial of efficacy, immunogenicity, and safety. Clinical infectious diseases : an official publication of the Infectious Diseases Society of America 2011, 52(1):128-137.

175. McAnerney JM, Treurnicht F, Walaza S, Cohen AL, Tempia S, Mtshali S, Buys A, Blumberg L, Cohen $C$ : Evaluation of influenza vaccine effectiveness and description of circulating strains in outpatient settings in South Africa, 2014. Influenza and other respiratory viruses 2015, 9(4):209-215.

176. McAnerney JM, Walaza S, Tempia S, Blumberg L, Treurnicht FK, Madhi SA, Valley-Omar Z, Cohen C: Estimating vaccine effectiveness in preventing laboratory-confirmed influenza in outpatient settings in South Africa, 2015. Influenza and other respiratory viruses 2017, 11(2):177-181.

177. Mutsaerts E, Madhi SA, Cutland CL, Jones S, Hugo A, Trenor S, Treurnicht FK, Klipstein-Grobusch K, Weinberg A, Nunes MC: Influenza vaccination of pregnant women protects them over two consecutive influenza seasons in a randomized controlled trial. Expert Rev Vaccines 2016, 15(8):1055-1062.

178. Njuguna H, Ahmed J, Oria PA, Arunga G, Williamson J, Kosgey A, Muthoka P, Mott JA, Breiman RF, Katz MA: Uptake and effectiveness of monovalent influenza A (H1N1) pandemic 2009 vaccine among healthcare personnel in Kenya, 2010. Vaccine 2013, 31(41):4662-4667.

179. Nunes MC, Cutland CL, Jones S, Downs S, Weinberg A, Ortiz JR, Neuzil KM, Simoes EAF, Klugman KP, Madhi SA: Efficacy of maternal influenza vaccination against all-cause lower respiratory tract infection hospitalizations in young infants: Results from a randomized controlled trial. Clinical infectious diseases : an official publication of the Infectious Diseases Society of America 2017.

180. Orenstein EW, Orenstein LA, Diarra K, Djiteye M, Sidibe D, Haidara FC, Doumbia MF, Diallo F, Coulibaly F, Keita AM et al: Cost-effectiveness of maternal influenza immunization in Bamako, Mali: A decision analysis. PLoS One 2017, 12(2):e0171499.

181. Victor JC, Lewis KD, Diallo A, Niang MN, Diarra B, Dia N, Ortiz JR, Widdowson MA, Feser J, Hoagland $R$ et al: Efficacy of a Russian-backbone live attenuated influenza vaccine among children in Senegal: a randomised, double-blind, placebo-controlled trial. Lancet Glob Health 2016, 4(12):e955-e965.

182. Diallo A, Victor JC, Feser J, Ortiz JR, Kanesa-Thasan N, Ndiaye M, Diarra B, Cheikh S, Diene D, 
Ndiaye T et al: Immunogenicity and safety of MF59-adjuvanted and full-dose unadjuvanted trivalent inactivated influenza vaccines among vaccine-naive children in a randomized clinical trial in rural Senegal. Vaccine 2018, 36(43):6424-6432.

183. Armitage EP, Camara J, Bah S, Forster AS, Clarke E, Kampmann B, de Silva TI: Acceptability of intranasal live attenuated influenza vaccine, influenza knowledge and vaccine intent in The Gambia. Vaccine 2018, 36(13):1772-1780.

184. Knight GM, Clarkson M, de Silva TI: Potential impact of influenza vaccine roll-out on antibiotic use in Africa. I Antimicrob Chemother 2018, 73(8):2197-2200.

185. Madhi SA, Nunes MC: Experience and challenges on influenza and pertussis vaccination in pregnant women. Hum Vaccin Immunother 2018, 14(9):2183-2188. 186. Mehrbod P, Abdalla MA, Njoya EM, Ahmed AS, Fotouhi F, Farahmand B, Gado DA, Tabatabaian M, Fasanmi OG, Eloff JN et al: South African medicinal plant extracts active against influenza $\mathrm{A}$ virus. $B M C$ Complement Altern Med 2018, 18(1):112.

187. Nunes MC, Madhi SA: Prevention of influenza-related illness in young infants by maternal vaccination during pregnancy. F1000Res 2018, 7:122.

188. Pecenka C, Munthali S, Chunga P, Levin A, Morgan W, Lambach P, Bhat N, Neuzil KM, Ortiz JR, Hutubessy R: Maternal influenza immunization in Malawi: Piloting a maternal influenza immunization program costing tool by examining a prospective program. PLoS One 2017, 12(12):e0190006.

189. Madhi SA, Nunes MC, Weinberg A, Kuwanda L, Hugo A, Jones S, van Niekerk N, Ortiz JR, Neuzil KM, Klugman KP et al: Contribution of Serologic Assays in the Evaluation of Influenza Virus Infection Rates and Vaccine Efficacy in Pregnant Women: Report From Randomized Controlled Trials. Clinical Infectious Diseases: an Official Publication of the Infectious Diseases Society of America 2017, 64(12):1773-1779.

190. Oladipo EK, Awoyelu EH, Oloke JK: Assessment of Baseline Antibodies to Pandemic Influenza A/ H1N1/2009 Virus in Ogbomoso, Oyo State, Nigeria. Pathog Glob Health 2018, 112(4):227-231.

191. Biggerstaff M, Cohen C, Reed C, Tempia S, McMorrow ML, Walaza S, Moyes J, Treurnicht FK, Cohen AL, Hutchinson P et al: A cost-effectiveness analysis of antenatal influenza vaccination among HIV-infected and HIV-uninfected pregnant women in South Africa. Vaccine 2019, 37(46):6874-6884.

192. Buchwald AG, Tamboura B, Haidara FC, Coulibaly F, Doumbia M, Diallo F, Boudova S, Keita AM, Sow SO, Kotloff $\mathrm{K}$ et al: Maternal Influenza Vaccina- tion and the Risk of Laboratory-Confirmed Influenza Among Household Contacts Under the Age of Five in Mali. The American Journal of Tropical Medicine and Hygiene 2019, 100(1):159-164.

193. Dawa J, Chaves SS, Ba Nguz A, Kalani R, Anyango E, Mutie D, Muthoka P, Tabu C, Maritim M, Amukoye E et al: Developing a seasonal influenza vaccine recommendation in Kenya: Process and challenges faced by the National Immunization Technical Advisory Group (NITAG). Vaccine 2019, 37(3):464-472.

194. Ho A, Mapurisa G, Madanitsa M, Kalilani-Phiri L, Kamiza S, Makanani B, Ter Kuile FO, Buys A, Treurnicht F, Everett D et al: Impact of Maternal HIV Infection and Placental Malaria on the Transplacental Transfer of Influenza Antibodies in Mother-Infant Pairs in Malawi, 2013-2014. Open Forum Infect Dis 2019, 6(10):ofz383.

195. Duque J, McMorrow ML, Cohen AL: Influenza vaccines and influenza antiviral drugs in Africa: are they available and do guidelines for their use exist? BMC Public Health 2014, 14:41.

196. Sambala EZ, Manderson L: Policy perspectives on post pandemic influenza vaccination in Ghana and Malawi. BMC Public Health 2017, 17(1):227.

197. Lohiniva AL, Barakat A, Dueger E, Restrepo S, El Aouad R: A qualitative study of vaccine acceptability and decision making among pregnant women in Morocco during the A (H1N1) pdm09 pandemic. PLoS One 2014, 9(10):e96244.

198. McAnerney JM, Walaza S, Cohen AL, Tempia S, Buys A, Venter M, Blumberg L, Duque J, Cohen C: Effectiveness and knowledge, attitudes and practices of seasonal influenza vaccine in primary healthcare settings in South Africa, 2010-2013. Influenza and other respiratory viruses 2015, 9(3):143-150.

199. Olatunbosun OD, Esterhuizen TM, Wiysonge CS: A cross sectional survey to evaluate knowledge, attitudes and practices regarding seasonal influenza and influenza vaccination among diabetics in Pretoria, South Africa. Vaccine 2017, 35(47):6375-6386.

200. Oria PA, Arunga G, Lebo E, Wong JM, Emukule G, Muthoka P, Otieno N, Mutonga D, Breiman RF, Katz MA: Assessing parents' knowledge and attitudes towards seasonal influenza vaccination of children before and after a seasonal influenza vaccination effectiveness study in low-income urban and rural Kenya, 20102011. BMC Public Health 2013, 13:391.

201. Otieno NA, Nyawanda BO, Audi A, Emukule G, Lebo E, Bigogo G, Ochola R, Muthoka P, Widdowson MA, Shay DK et al: Demographic, socio-economic and geographic determinants of seasonal influenza vac- 
cine uptake in rural western Kenya, 2011. Vaccine 2014, 32(49):6699-6704.

202. Coulibaly D, Nzussouo NT, Kadjo HA, Traore Y, Ekra DK, Cherif D, Kouassi PD, N'Gattia A K, Dagnan SN: Pandemic Influenza A(H1N1) in Cote d'Ivoire: health-care providers' knowledge of influenza and attitudes towards vaccination. J Infect Dev Ctries 2013, 7(7):499-506.

203. Kouassi DP, Coulibaly D, Foster L, Kadjo H, N'Zussuouo T, Traore Y, Cherif D, N'Gattia A K, Thompson MG: Vulnerable groups within a vulnerable population: awareness of the $\mathrm{A}(\mathrm{H} 1 \mathrm{~N} 1) \mathrm{pdm} 09$ pandemic and willingness to be vaccinated among pregnant women in Ivory Coast. The Journal of Infectious Diseases 2012, 206 Suppl 1:S114-120.

204. Oria PA, Matini W, Nelligan I, Emukule G, Scherzer M, Oyier B, Ochieng HN, Hooper L, Kanyuga A, Muthoka P et al: Are Kenyan healthcare workers willing to receive the pandemic influenza vaccine? Results from a cross-sectional survey of healthcare workers in Kenya about knowledge, attitudes and practices concerning infection with and vaccination against 2009 pandemic influenza A (H1N1), 2010. Vaccine 2011, 29(19):36173622.

205. Duque J, Gaga S, Clark D, Muller M, Kuwane B, Cohen C, Walaza S, Tempia S, Ramatoboe P, Furumele $\mathrm{T}$ et al: Knowledge, attitudes and practices of South African healthcare workers regarding the prevention and treatment of influenza among HIV-infected individuals. PLoS One 2017, 12(3):e0173983.

206. McMorrow ML, Emukule GO, Obor D, Nyawanda B, Otieno NA, Makokha C, Mott JA, Bresee JS, Reed C: Maternal influenza vaccine strategies in Kenya: Which approach would have the greatest impact on disease burden in pregnant women and young infants? PLoS One 2017, 12(12):e0189623.

207. Phiri M, Gooding K, Peterson I, Mambule I, Nundwe S, McMorrow M, Desmond N: Dust or disease? Perceptions of influenza in rural Southern Malawi. PLoS One 2019, 14(4):e0208155.

208. Ben M'hadheb M, Harrabi M, Souii A, Jrad-Battikh N, Gharbi J: Multiplex RT-PCR and indirect immunofluorescence assays for detection and subtyping of human influenza virus in Tunisia. Curr Microbiol 2015, 70(3):324-329.

209. Feikin DR, Njenga MK, Bigogo G, Aura B, Gikunju S, Balish A, Katz MA, Erdman D, Breiman RF: Additional diagnostic yield of adding serology to PCR in diagnosing viral acute respiratory infections in Kenyan patients 5 years of age and older. Clin Vaccine Immunol 2013, 20(1):113-114.
210. Kenmoe S, Tchendjou P, Moyo Tetang S, Mossus T, Njankouo Ripa M, Guillet M, Kfutwah A, Njouom $\mathrm{R}$ : Evaluating the performance of a rapid antigen test for the detection of influenza virus in clinical specimens from children in Cameroon. Influenza and other respiratory viruses 2014, 8(2):131-134.

211. Ndegwa LK, Emukule G, Uyeki TM, Mailu E, Chaves SS, Widdowson MA, Lewa BV, Muiruri FK, Omoth P, Fields B et al: Evaluation of the point-of-care Becton Dickinson Veritor Rapid influenza diagnostic test in Kenya, 2013-2014. BMC Infectious Diseases 2017, 17(1):60.

212. Pretorius MA, Madhi SA, Cohen C, Naidoo D, Groome M, Moyes J, Buys A, Walaza S, Dawood H, Chhagan $\mathrm{M}$ et al: Respiratory viral coinfections identified by a 10 -plex real-time reverse-transcription polymerase chain reaction assay in patients hospitalized with severe acute respiratory illness--South Africa, 2009-2010. The Journal of Infectious Diseases 2012, 206 Suppl 1:S159-165.

213. Halima B. Maïnassara, Adamou Lagare, Stefano Tempia, Ali Sidiki, Bassira Issaka, Sidikou BA, Oukem-Boyer OOM: Influenza Sentinel Surveillance among Patients with Influenza-Like-Illness and Severe Acute Respiratory Illness within the Framework of the National Reference Laboratory, Niger, 2009-2013 PLoS One 2015, 10(7):e0133178.

214. Tarnagda Z, Yougbare I, Ilboudo AK, Kagone T, Sanou AM, Cisse A, Medah I, Yelbeogo D, Talla Nzussouo N: Sentinel surveillance of influenza in Burkina Faso: identification of circulating strains during 20102012. Influenza and other respiratory viruses 2014, 8(5):524529.

215. Walaza S, Tempia S, Dawood H, Variava E, Moyes J, Cohen AL, Wolter N, Groome M, von Mollendorf $\mathrm{C}$, Kahn $\mathrm{K}$ et al: Influenza virus infection is associated with increased risk of death amongst patients hospitalized with confirmed pulmonary tuberculosis in South Africa, 2010-2011. BMC Infectious Diseases 2015, 15:26.

216. Emukule GO, Khagayi S, McMorrow ML, Ochola R, Otieno N, Widdowson MA, Ochieng M, Feikin DR, Katz MA, Mott JA: The Burden of Influenza and RSV among Inpatients and Outpatients in Rural Western Kenya, 2009-2012. PLoS One 2014, 9(8):e105543.

217. Feikin DR, Njenga MK, Bigogo G, Aura B, Aol G, Audi A, Jagero G, Muluare PO, Gikunju S, Nderitu $\mathrm{L}$ et al: Etiology and Incidence of viral and bacterial acute respiratory illness among older children and adults in rural western Kenya, 2007-2010. PLoS One 2012, 7(8):e43656.

218. Ghani AS, Morrow BM, Hardie DR, Argent AC: 
An investigation into the prevalence and outcome of patients admitted to a pediatric intensive care unit with viral respiratory tract infections in Cape Town, South Africa. Pediatr Crit Care Med 2012, 13(5):e275-281.

219. Nunes MC, Madhi SA: Influenza vaccination during pregnancy for prevention of influenza confirmed illness in the infants: A systematic review and meta-analysis. Hum Vaccin Immunother 2017:1-9.

220. Schoub BD, McAnerney JM, Besselaar TG: Regional perspectives on influenza surveillance in Africa. Vaccine 2002, 20 Suppl 2:S45-46.

221. Katz MA, Schoub BD, Heraud JM, Breiman RF, Njenga MK, Widdowson MA: Influenza in Africa: uncovering the epidemiology of a long-overlooked disease. The Journal of Infectious Diseases 2012, 206 Suppl 1:S1-4.

222. Van Kerkhove MD, Cooper MJ, Cost AA, Sanchez JL, Riley S: Risk factors for severe outcomes among members of the United States military hospitalized with pneumonia and influenza, 2000-2012. Vaccine 2015, 33(49):6970-6976.

223. Van Kerkhove MD, Vandemaele KA, Shinde V, Jaramillo-Gutierrez G, Koukounari A, Donnelly CA, Carlino LO, Owen R, Paterson B, Pelletier L et al: Risk factors for severe outcomes following 2009 influenza A (H1N1) infection: a global pooled analysis. PLoS Med 2011, 8(7):e1001053.

224. Walaza S, Cohen C, Tempia S, Moyes J, Nguweneza A, Madhi SA, McMorrow M, Cohen AL: Influenza and tuberculosis co-infection: A systematic review. Influenza and other respiratory viruses 2019.

225. WHO: WHO Global Influenza Surveillance and Response System. 2015. https://www.who.int/influenza/gisrs_laboratory/flunet/en/ (assessed on 30 July 2019)

226. Czarkowski MP, Hallmann-Szelinska E, Staszewska E, Bednarska K, Kondratiuk K, Brydak LB: Influenza in Poland in 2011-2012 and in 2011/2012 and 2012/2013 epidemic seasons. Prregl Epidemiol 2014, 68(3):455-463, 559-465.

227. Ntshoe GM, McAnerney JM, Tempia S, Blumberg L, Moyes J, Buys A, Naidoo D, Venter M, Besselaar T, Schoub BD et al: Influenza epidemiology and vaccine effectiveness among patients with influenza-like illness, viral watch sentinel sites, South Africa, 2005-2009. PLoS One 2014, 9(4):e94681.

228. Sambala EZ, Mdolo A, Banda R, Phiri A, Wiyeh $A B$, Wiysonge CS: Burden of seasonal influenza in sub-Saharan Africa: a systematic review protocol. $B M J$ Open 2018, 8(10):e022949.

229. Lafond KE, Nair H, Rasooly MH, Valente F, Booy R, Rahman M, Kitsutani P, Yu H, Guzman G, Coulibaly $D$ et al: Global Role and Burden of Influenza in Pediatric Respiratory Hospitalizations, 1982-2012: A Systematic Analysis. PLoS Med 2016, 13(3):e1001977.

230. Fuller JA, Summers A, Katz MA, Lindblade KA, Njuguna H, Arvelo W, Khagayi S, Emukule G, Linares-Perez N, McCracken J et al: Estimation of the national disease burden of influenza-associated severe acute respiratory illness in Kenya and Guatemala: a novel methodology. PLoS One 2013, 8(2):e56882.

231. Tempia S, Walaza S, Moyes J, Cohen AL, von Mollendorf C, McMorrow ML, Mhlanga S, Treurnicht FK, Venter M, Pretorius $M$ et al: The effects of the attributable fraction and the duration of symptoms on burden estimates of influenza-associated respiratory illnesses in a high HIV prevalence setting, South Africa, 2013-2015. Influenza and other respiratory viruses 2018, 12(3):360-373.

232. O'Brien MA, Uyeki TM, Shay DK, Thompson WW, Kleinman K, McAdam A, Yu XJ, Platt R, Lieu TA: Incidence of outpatient visits and hospitalizations related to influenza in infants and young children. Pediatrics 2004, 113(3 Pt 1):585-593.

233. Bhuiyan MU, Luby SP, Alamgir NI, Homaira N, Mamun AA, Khan JA, Abedin J, Sturm-Ramirez K, Gurley ES, Zaman RU et al: Economic burden of influenza-associated hospitalizations and outpatient visits in Bangladesh during 2010. Influenza and other respiratory viruses 2014, 8(4):406-413.

234. Putri W, Muscatello DJ, Stockwell MS, Newall AT: Economic burden of seasonal influenza in the United States. Vaccine 2018, 36(27):3960-3966.

235. Cuningham W, Geard N, Fielding JE, Braat S, Madhi SA, Nunes MC, Christian LM, Lin SY, Lee CN, Yamaguchi $\mathrm{K}$ et al: Optimal timing of influenza vaccine during pregnancy: A systematic review and meta-analysis. Influenza and other respiratory viruses 2019, 13(5):438452. 